\title{
Ultramicronized Palmitoylethanolamide (um-PEA): A New Possible Adjuvant Treatment in COVID-19 patients
}

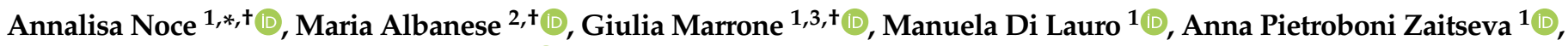 \\ Daniela Palazzetti ${ }^{1}$, Cristina Guerriero ${ }^{1}{ }^{1}$, Agostino Paolino ${ }^{4}$, Giuseppa Pizzenti ${ }^{5}$, Francesca Di Daniele 1,3, \\ Annalisa Romani ${ }^{6}$, Cartesio D'Agostini ${ }^{7,8}$, Andrea Magrini ${ }^{4}$, Nicola Biagio Mercuri ${ }^{2,9}\left(\mathbb{C}\right.$ and Nicola Di Daniele ${ }^{1} \mathbb{C}$
}

check for

updates

Citation: Noce, A.; Albanese, M.; Marrone, G.; Di Lauro, M.; Pietroboni Zaitseva, A.; Palazzetti, D.; Guerriero,

C.; Paolino, A.; Pizzenti, G.; Di

Daniele, F.; et al. Ultramicronized

Palmitoylethanolamide (um-PEA): A

New Possible Adjuvant Treatment in COVID-19 patients. Pharmaceuticals 2021, 14, 336. https://doi.org/ $10.3390 /$ ph14040336

Academic Editors: Jean Jacques Vanden Eynde and Annie Mayence

Received: 4 March 2021

Accepted: 30 March 2021

Published: 6 April 2021

Publisher's Note: MDPI stays neutral with regard to jurisdictional claims in published maps and institutional affiliations.

Copyright: (C) 2021 by the authors Licensee MDPI, Basel, Switzerland. This article is an open access article distributed under the terms and conditions of the Creative Commons Attribution (CC BY) license (https:/ / creativecommons.org/licenses/by/ $4.0 /)$
1 UOC of Internal Medicine-Center of Hypertension and Nephrology Unit, Department of Systems Medicine, University of Rome Tor Vergata, 00133 Rome, Italy; giul.marr@gmail.com (G.M.); dilauromanuela@gmail.com (M.D.L.); annapietroboni@icloud.com (A.P.Z.); daniela.palazzetti96@gmail.com (D.P.); cristinaguerriero@hotmail.it (C.G.); francesca.didaniele@gmail.com (F.D.D.); didaniele@med.uniroma2.it (N.D.D.)

2 Neurology Unit, Department of Systems Medicine, University of Rome Tor Vergata, 00133 Rome, Italy; maria.albanese@hotmail.it (M.A.); mercurin@med.uniroma2.it (N.B.M.)

3 PhD School of Applied Medical, Surgical Sciences, University of Rome Tor Vergata, 00133 Rome, Italy

4 Department of Biomedicine and Prevention, University of Rome Tor Vergata, 00133 Rome, Italy; agostino.paolino.pv@gmail.com (A.P.); andrea.magrini@uniroma2.it (A.M.)

5 School of Specialization in Geriatrics, University of Rome Tor Vergata, 00133 Rome, Italy; giusypizzenti@gmail.com

6 PHYTOLAB (Pharmaceutical, Cosmetic, Food Supplement, Technology and Analysis), DiSIA, University of Florence, Sesto Fiorentino, 50019 Florence, Italy; annalisa.romani@unifi.it

7 Department of Experimental Medicine, University of Rome Tor Vergata, 00133 Rome, Italy; cartesio.dagostini@ptvonline.it

8 Laboratory of Clinical Microbiology, Policlinico Tor Vergata, 00133 Rome, Italy

9 IRCCS Santa Lucia Foundation, 00179 Rome, Italy

* Correspondence: annalisa.noce@uniroma2.it; Tel.: +39-06-2090-2194

+ These authors equally contributed to this work.

Abstract: The Coronavirus Disease-19 (COVID-19) pandemic has caused more than 100,000,000 cases of coronavirus infection in the world in just a year, of which there were 2 million deaths. Its clinical picture is characterized by pulmonary involvement that culminates, in the most severe cases, in acute respiratory distress syndrome (ARDS). However, COVID-19 affects other organs and systems, including cardiovascular, urinary, gastrointestinal, and nervous systems. Currently, unique-drug therapy is not supported by international guidelines. In this context, it is important to resort to adjuvant therapies in combination with traditional pharmacological treatments. Among natural bioactive compounds, palmitoylethanolamide (PEA) seems to have potentially beneficial effects. In fact, the Food and Drug Administration (FDA) authorized an ongoing clinical trial with ultramicronized (um)-PEA as an add-on therapy in the treatment of Severe Acute Respiratory Syndrome Coronavirus-2 (SARS-CoV-2) infection. In support of this hypothesis, in vitro and in vivo studies have highlighted the immunomodulatory, anti-inflammatory, neuroprotective and painrelieving effects of PEA, especially in its um form. The purpose of this review is to highlight the potential use of um-PEA as an adjuvant treatment in SARS-CoV-2 infection.

Keywords: COVID-19; SARS-CoV-2; ultramicronized palmitoylethanolamide; organ damage; neuroinflammation; adjuvant treatment

\section{Introduction}

In late 2019, an unknown pneumonia started to spread, with initial cases found in the town of Wuhan, China. It was later identified as the cause in a new beta-coronavirus, a member of the Coronaviridae family, called Severe Acute Respiratory Syndrome Coronavirus-2 (SARS-CoV-2), which has shown important similarities with two other members of that 
family, SARS-CoV (which caused an outbreak in 2002-2003) and the Middle East Respiratory Syndrome Coronavirus Infection (MERS-CoV; found in an outbreak from the Middle East in 2012) [1,2]. SARS-Cov-2 has rapidly spread from China around the world, thanks to human-to-human transmission and its high contagiousness, causing a disease called Coronavirus Disease-19 (COVID-19), currently responsible for over 100 million infections and 2 million deaths worldwide in more than 200 countries [3].

There is enormous variability regarding the clinical manifestations of COVID-19. In fact, affected subjects can be asymptomatic or show symptoms that are mild, moderate, or severe (which can have bad outcomes). The most common symptoms are represented by fever, dry cough, muscle aches, "shortness of breath", and headache, while symptoms such as rhinorrhea, sore throat, and those affecting the gastrointestinal system are rarer [4]. More severe complications include respiratory failure, neurological symptoms, acute kidney injury (AKI), shock, and death [5].

The lungs are the most affected organs. Respiratory symptoms are certainly the most frequent; however, other organs can be affected, and there are numerous extrarespiratory manifestations [6]. Cardiac complications such as acute heart failure, myocarditis, arrhythmia, and shock [7], gastrointestinal symptoms such as diarrhea, nausea, vomiting, and abdominal pain [8], liver damage with high levels of aspartate aminotransferase (AST) and alanine aminotransferase (ALT) [9], and cutaneous alterations such as rash and skin lesions [10] have been reported in COVID-19 patients. Furthermore, neurological manifestations like hyposmia, hypogeusia, headache, and dizziness have also been documented [11]. Meanwhile, acute cerebrovascular diseases, impaired consciousness, and epilepsy have been occasionally described in COVID-19 patients [12]. All the severe organ damages observed in SARS-CoV-2 infection are mainly characterized by an inflammatory process [13]. The kidney is another organ particularly involved in the course of SARS-CoV-2 infection; in fact, numerous cases of AKI have been recorded, which increase the risk of death by 3 times compared to COVID-19 patients without renal involvement [14].

Currently, there are no totally effective antiviral drugs against SARS-CoV-2. The drugs currently in use are designed to counteract the symptoms of infection and are based on anti-inflammatory and immunomodulatory effects and on antiviral actions observed in in-vitro studies. These drugs are not specifically for the treatment of COVID-19 and have numerous limitations in their use [15]. For this reason, in addition to traditional drugs, a possible adjuvant treatment could be represented by natural bioactive compounds (NBCs). Nowadays, there are numerous studies investigating the possible role of oral food supplements based on NBCs in alleviating COVID-19 symptoms. Among these, a very interesting one is palmitoylethanolamide (PEA), an amide of palmitic acid with well-known anti-inflammatory properties, on which this review focuses.

\section{Ultramicronized-PEA and its Mechanisms of Action}

PEA is an amide of endogenous fatty acid of the $\mathrm{N}$-acylethanolamine family, naturally produced in the body and largely found in several food sources, as reported in Figure 1 [16]. The food content of PEA varies from $950.000 \mathrm{ng} \cdot \mathrm{g}^{-1}$ in soy lecithin to $0.25 \mathrm{ng} \cdot \mathrm{g}^{-1}$ in bovine milk [17].

PEA is a cannabimimetic compound that performs a wide variety of biological functions to counteract chronic pain and inflammation [18-23]. In the current state of knowledge, PEA is considered by the international scientific community as an oral food supplement with immunomodulatory, anti-inflammatory, neuroprotective, and pain-relieving properties [22]. Historically, between the 1960s and 1970s, PEA was used in the drug "Impulsin" to treat flu and cold, proving to be especially effective in prophylaxis and in the treatment of upper respiratory tract infections [24,25]. 


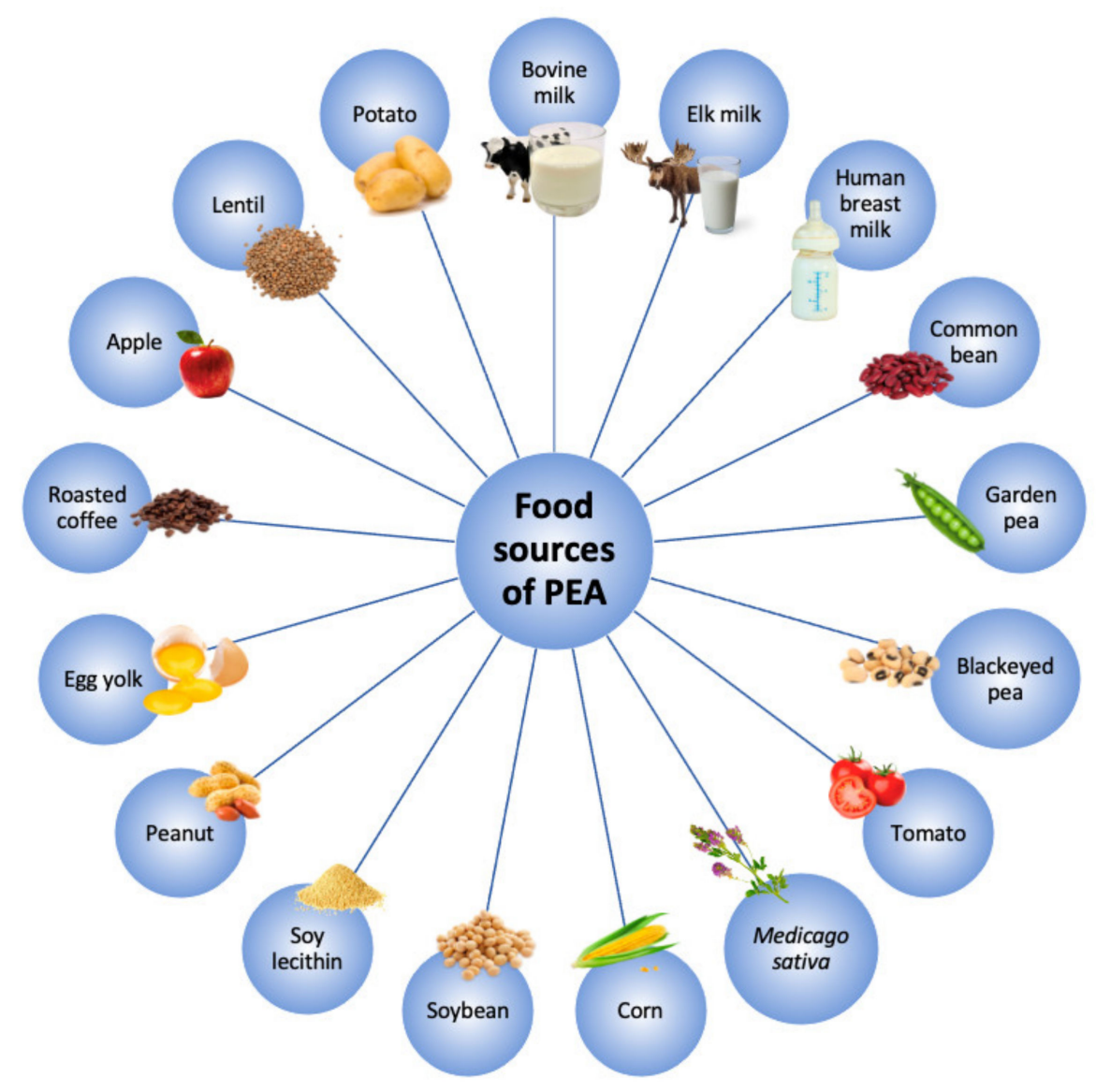

Figure 1. Main food sources of palmitoylethanolamide (PEA).

Nowadays, in the literature, the available data on PEA pharmacokinetics and bioavailability are few [17]. An interesting animal-model study on PEA pharmacokinetics showed that after oral administration, the drug reaches its highest concentration in $15 \mathrm{~min} ; 2 \mathrm{~h}$ later, it comes back to basal values [26]. Subsequently, to enhance the biodisponibility of PEA, two new formulations were synthesized: micronized-PEA and ultramicronized-PEA (um-PEA). In particular, um-PEA displays better bioavailability compared to its native form, with improved effectiveness [27]. In fact, in an animal-model, um-PEA concentration was higher, up to six times, after 1-2 $\mathrm{h}$ from oral administration compared to the native form [28].

The main um-PEA immunomodulatory effect seems to be related to mast cells $[29,30]$, which are typically involved in respiratory infections caused by coronaviruses and/or other influenza viruses [31,32]. This mechanism of action was first hypothesized by Rita Levi Montalcini et al., who described the downregulation of mast cells via the "autacoid local injury antagonism" [33].

um-PEA is able to inhibit the release and action of mast cells, reduce the expression of cyclooxygenase-2 (COX-2) and inducible nitric oxide synthase (iNOS) [34], and counteract the release of proinflammatory proteases, histamine, cytokines, and chemokines (also implicated in COVID-19) [35,36]. Moreover, um-PEA exerts its immunomodulatory action as an agonist, binding to peroxisome proliferator-activated receptor alpha (PPAR $\alpha$ ), which is expressed at the level of different organs but especially in the immune cells such as monocytes, macrophages, and T- and B-lymphocytes [37]. In fact, as already underlined, um-PEA regulates the hyperactivation of mast cells [38] by reducing their migration and degranulation, and it mediates the overactivation of both astrocytes and glial cells $[29,30]$. These actions are responsible for numerous pathological conditions such as those related to asthma and allergies [39], fibromyalgia [40], and chronic lung diseases [41]. For these 
reasons, um-PEA may exert respiratory protective effects, making it a promising candidate for the adjuvant treatment of COVID-19 [25].

PEA is also able to interact with cannabinoid receptors [42,43], ATP-sensitive K+ and transient receptor potential vanilloid type-1 (TRPV1) channels [44,45], nuclear factor kappa-light-chain-enhancer of activated B-cells (NF-kB) [46], G-protein-coupled receptors 55 (GPR55) [47], and PPAR $\alpha$ [48], exerting anti-inflammatory and pain-relieving actions $[19,49]$. In particular, um-PEA, having a chemical structure similar to classic endocannabinoids, enhances their effects, counteracting their catabolism and increasing their concentration (entourage effect) [42,50]. This PEA-specific action is mainly mediated by the TRPV1 channel, whose activation seems to be indirectly induced by two different mechanisms. The first one is related to the entourage effect [51]; meanwhile, the second is mediated by $\operatorname{PPAR} \alpha$ [52].

In addition, um-PEA is able to decrease hyperalgesia as it can reduce COX-2 and iNOS gene transcription and restore the action of PPAR $\alpha$ at the dorsal root ganglia level. In fact, um-PEA seems to inhibit the degradation of IkB- $\alpha$ and the nuclear translocation of p65 NF$\kappa \mathrm{B}$, acting as a transcription modulator for the attenuation of peripheral hyperalgesia, with inhibition of the release of inflammatory cytokines such as tumor necrosis factor- $\alpha$ (TNF- $\alpha)$ and some interleukins (ILs) [25,46,53]. Further action of um-PEA can be related to direct activation at low doses of the orphan GPR55 receptor, largely expressed in many brain areas and in the gastrointestinal system [17,54,55]. Although GPR55 physiological action is not completely known, it seems to act through the activation of several mediators (such as Gq G12, RhoA, actin, PLC, and IP(3)R-gated stores), enhancing intracellular calcium [56].

New evidence shows that in the case of COVID-19, mast cells are activated by Toll-like receptors (TLRs), increasing inflammation in the lungs and inducing fibrosis [34,57]. umPEA treatment may be able to modulate the mechanisms linked to PPAR $\alpha$ and TLRs that are involved in SARS-CoV-2 infection [58]. In addition to the actions described above, umPEA is also able to reduce oxidative stress and improve endothelial damage, the intestinal barrier integrity, and brain function [59-63].

In this regard, the consequent positive role of um-PEA on the central nervous system (CNS) is represented by the reduction of neuroinflammation, acting on the mast cell-microglia axis [42,50]. Through the activation of PPAR $\alpha$, um-PEA is able to stimulate the synthesis of neurosteroids [48]. This action would seem to be regulated by two mechanisms. The first is characterized by molecular control through high conductance potassium channels (IKCa and BKCa), which, once opened, trigger the silencing of neuronal activation. The second one consists of activating gene transcription, with subsequent neurosteroid synthesis $[64,65]$.

In recent years, several studies have investigated how the um-PEA compound may exert a neuroprotective action $[17,66]$. In vitro and in vivo studies have shown um-PEA's ability to stimulate neurogenesis and promote the release of neurotrophic factors [67]. In fact, um-PEA is able to interact with some GPRs to stimulate the ligand-activated nuclear receptor PPAR $\alpha$ subtype, which promotes the regulation of lipids, carbohydrates, and amino acid metabolism and of inflammation mediators [68]. PPAR $\alpha$ is widely expressed at the glial level, where it plays a protective role in the suppression of neuroinflammation and the inhibition of oxidative stress $[69,70]$.

Activation of $\operatorname{PPAR} \alpha$, present on astrocytes, regulates the activity of modulating genes for both the expression of glial glutamate transporters and the transcription of neurosteroids (first of all, allopregnanolone) [65,71] (Figure 2). 


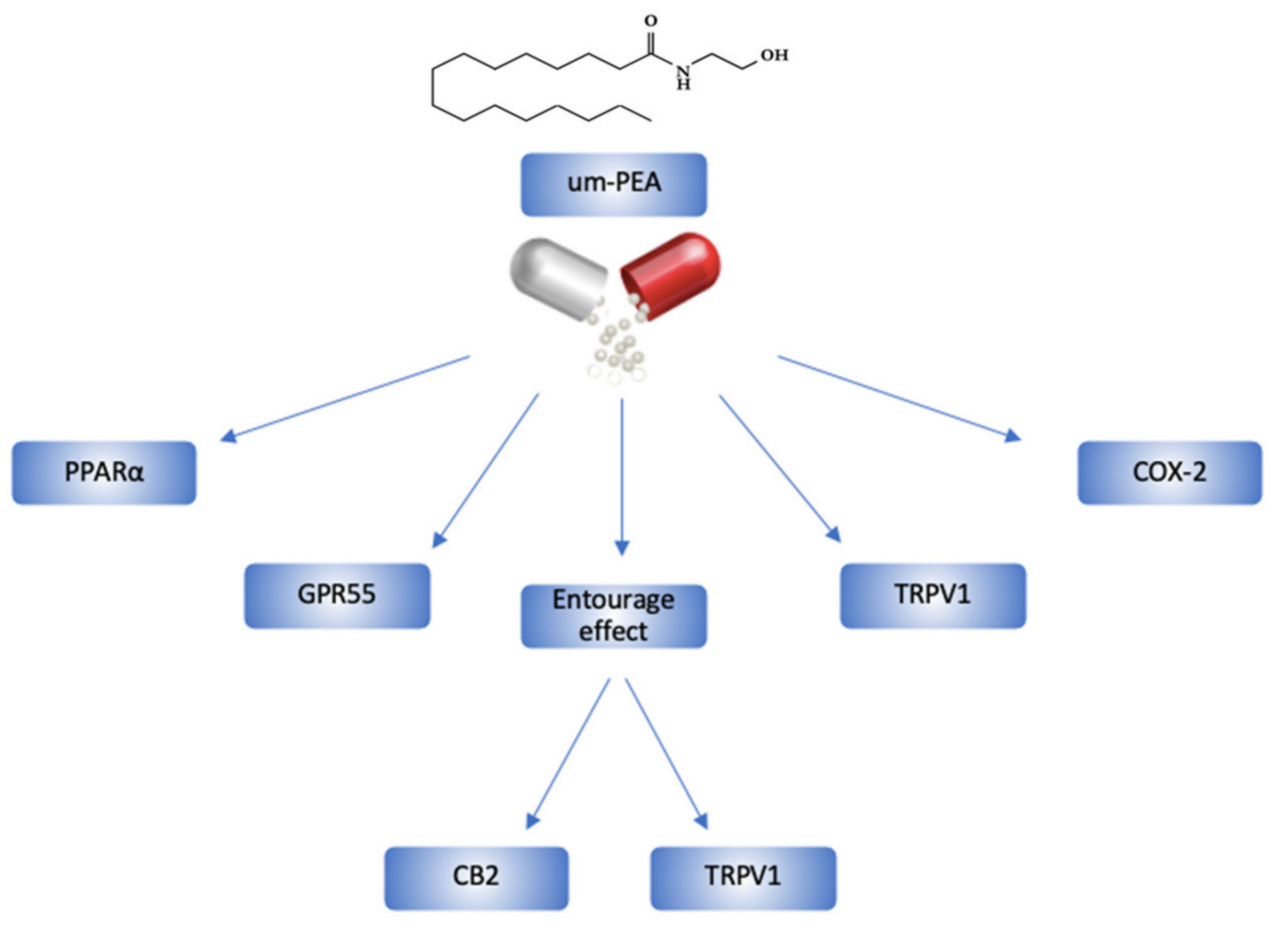

Figure 2. um-PEA's chemical structure and its mechanism of action in the human body. CB2, cannabinoid 2; COX-2, cyclooxygenase-2; GPR55, G-protein-coupled receptors 55; PPAR $\alpha$, peroxisome proliferator-activated receptor $\alpha$; TRPV1, transient receptor potential vanilloid type-1.

\section{Pathogenic Mechanisms of SARS-CoV-2}

SARS-CoV-2 is a single-stranded RNA $\beta$-coronavirus formed by an envelope containing a lipid membrane and protein components (the spike (S) glycoprotein, the envelope (E) protein, and the membrane (M) protein). The genomic component of single-stranded RNA is bound to the nucleocapsid (N) protein. The S protein needs to be cleaved into S1 and S2 portions by transmembrane serine protease 2 (TMPRSS2) to be functional and to penetrate host cells. The S1 portion binds the receptor angiotensin-converting enzyme 2 (ACE2) that induces receptor-mediated endocytosis of the virion into the host cell. The binding affinity between S-protein and ACE-receptors is 10-20-fold higher compared to other coronaviruses; this affinity explains the easier human-to-human transmission [72,73].

The most important way of spreading SARS-CoV-2 is through droplets and direct contact with mucosa, but many studies have pointed out other transmission ways, such as fomites, aerosol, and transplacental via birth [74].

Although in the beginning, SARS-CoV-2 was considered a respiratory disease, it has been demonstrated that the virus can infect many kinds of human cells because of the presence of a great number of ACE-receptors in many organs. In nasal mucosa, high levels of angiotensin-converting enzyme 2 (ACE2) expression were found in secretory goblet cells, and this may explain the high tropism of SARS-CoV-2 for this type of cells [75]. The virus starts its replication in the upper respiratory tract, and in up to $20 \%$ of patients, the infection spreads to the lungs, where the epithelial cells represent the most important target due to the high expression of ACE2 and TMPRSS2 receptors. Moreover, it has been demonstrated that the virus also infects macrophages. This leads to the apoptosis of lung epithelial cells, which triggers an important inflammatory response, with the recruitment of immune cells that eliminate the infected cells [76]. This phase represents the start of the "cytokine storm", which has been pointed out in the most-ill COVID-19 patients. The spreading to the immune cells during the inflammatory response represents the main cause of alveolar damage and hemorrhage. Moreover, interstitial modifications have been reported in in-vitro studies [77]. 
Although the COVID-19 initial phase occurs in the lungs, studies have shown that the virus can spread to many other organs and tissues [78]. An important contribution to COVID-19 immunopathology is given by the spreading of the virus into vessels and blood cells. It can easily enter the platelets because of the high expression of ACE2 and TMPRSS2 receptors on the surface of these cells $[79,80]$. Moreover, the interaction between viral S-protein and the platelets' glycoproteins can directly induce platelet activation that results in the release of coagulation factors and cytokines; this, in turn, contributes to thrombosis and hemostasis. The latter are caused by the adhesion of activated platelets to the subendothelium. In the lung, the hyperactivity of the platelets contributes to the enhancement of the inflammatory response, inducing vessel ischemia and embolism through the activation of the coagulation cascade [81]. Currently, it has been confirmed that the most important cause of death due to SARS-CoV-2 infection is related to coagulopathy induced by the inflammatory response, which ends with disseminated intravascular coagulation (DIC) [82].

In addition to alveolar damage that can potentially become critical, above all, in elderly and immunosuppressed patients and in the presence of comorbidities (such as cancer, obesity, metabolic syndrome, cardiovascular diseases), SARS-CoV-2 infection can involve many other tissues and organs since this virus has a wide organotropism.

It has been pointed out that through the olfactory nerve starting from the nasal epithelium, the virus can invade the CNS, which can also be reached hematogenously [83]. Moreover, ACE2 has also been found at high rates in different neurological cells, such as neurons and glial cells. Nonetheless, ACE2 and TMPRSS2 receptors can be found on the surface of cardiomyocytes, kidney cells, the liver, and the pancreas, in the gastrointestinal tract, and at very high rates in the gallbladder [84].

Recent studies have focused on how SARS-CoV-2 systemic infection causes endothelial dysfunction and coagulopathy. In this context, systemic inflammation and cytokine release seem to play important roles in the onset of pneumonia and other symptoms. The importance of the "cytokine storm" has been pointed out in many studies $[13,85,86]$ : once activated, the "endothelium dysfunction-platelets activation-inflammatory response-rise of cytokines releasing-tissue injury" loop can easily spread to many organs and tissues.

\section{Main Organ Damage Induced by SARS-CoV-2}

In the early stages, SARS-CoV-2 infection manifests itself clinically with muscle aches, headache, fatigue, diarrhea, chills, fever, and cough. Thereafter, the patients may present respiratory symptoms such as "shortness of breath" and dry cough. Some subjects may get worse with severe pneumonia. Pneumonia can subsequently progress to acute respiratory distress syndrome (ARDS) and multiorgan failure (MOF), leading to patient death [87]. The severity of the disease depends on several factors, such as age and the presence of other comorbidities. The mechanism of SARS-CoV-2 infection is determined by binding with ACE2, through which the virus enters host cells. ACE2 is present in the respiratory, intestinal, renal, and cardiovascular systems and the immune cells. Consequently, associated with SARS-CoV-2, there may be a number of complications that do not exclusively affect the respiratory system but also the cardiovascular, gastrointestinal, and urinary systems (Figure 3) [88]. 


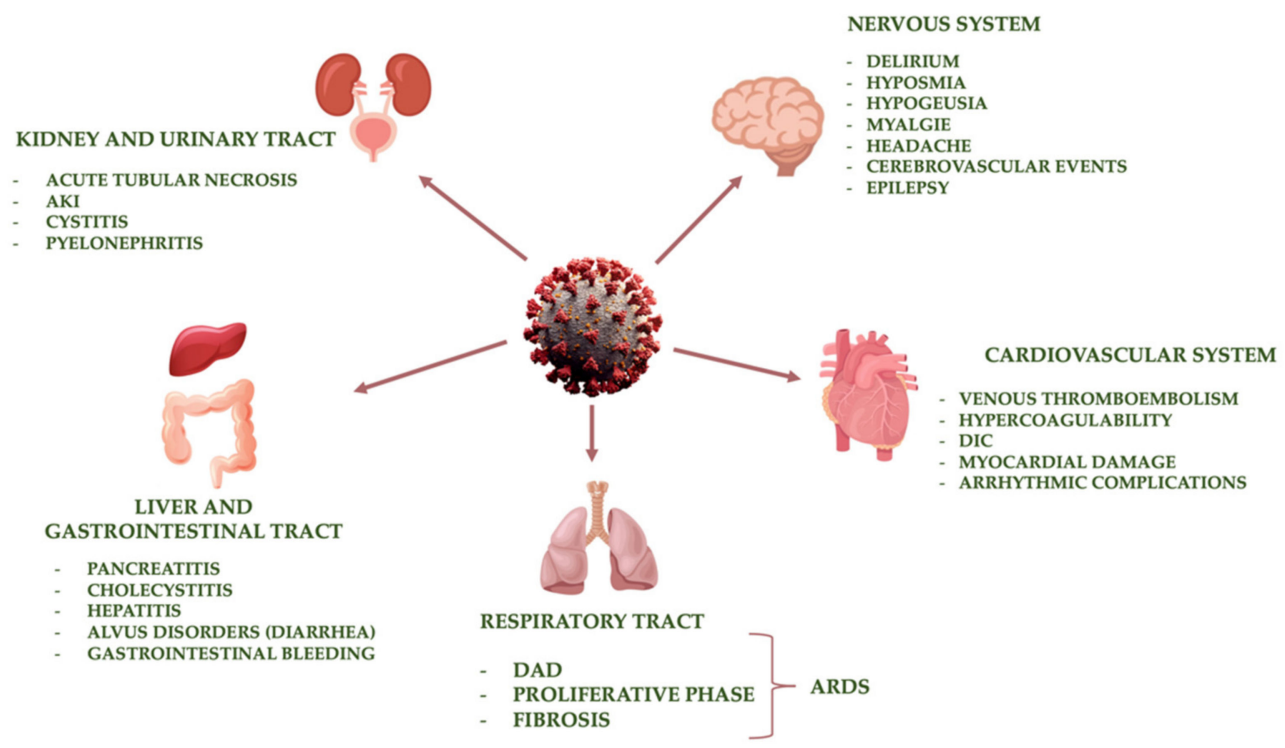

Figure 3. Main target organs of SARS-CoV-2 infection. Abbreviations: AKI, acute kidney injury; ARDS, acute respiratory distress syndrome; DAD, diffuse alveolar damage; DIC, disseminated intravascular coagulation.

\subsection{Respiratory Tract}

One of the fastest and most dangerous manifestations of SARS-CoV-2 infection is pulmonary damage, probably because of the high presence of ACE2 receptors on the alveolar surface of type II pneumocytes $[89,90]$. In the initial phase of infection, the virus leads to lower-airway damage [91]. Most patients with pulmonary involvement will soon show diffuse alveolar damage (DAD) [92], including alveolar edema and hemorrhage, fibrin exudation in alveolar spaces, bronchiolar damage, and hyaline membrane formation that is linked to epithelial cell necrosis [93]. According to the severity of COVID-19 disease, a second phase, characterized by a proliferative path, can follow the first-it includes tissue alterations such as the formation of fibromyxoid-organizing exudates, hyperplasia (especially of type II pneumocytes), and the widening of septae [94]. The inflammatory and proliferative response can subsequently induce a third fibrotic phase that can be pointed out in most patients who have died from severe pneumonia and ARDS induced by SARS-CoV-2 [95].

The initial apoptosis and the necrosis of pulmonary cells trigger an inflammatory response that increases tissue damage. This leads to the activation of the "cytokines storm", characterized by the acute release of proinflammatory cytokines, such as IL-6, IL-1, TNF- $\alpha$, and interferon, that are produced by macrophages, mast cells, and endothelial cells [96]. Released cytokines recall macrophages, neutrophils, and T-lymphocytes to the infection site, inducing and amplifying tissue damage [78,97]. During COVID-19, the inflammatory process alters the antithrombotic endothelial protective mechanisms. These include the release of nitric oxide with vasodilatory action, the secretion of prostaglandin (PG)I2, which inhibits the recruitment and activation of leukocytes, and, finally, the presence on the endothelial surface of CD39 receptors, which inhibit platelet aggregation. Therefore, the endothelial damage induced by SARS-CoV-2 leads to the loss of such protective mechanisms, provoking thromboembolic phenomena [98]. Thromboembolism plays a key role in inducing lung damage and injury at other tissue levels: in the early stage, the coagulation is activated by the immunological response and leads to the thrombosis of both small arteries and veins, causing successive pulmonary embolism [99]. The absence of blood flow contributes to tissue damage and necrosis, and represents one of the first triggers to the worsening of clinical features, characterized by the reduction of oxygen saturation due to, in turn, a significant ventilation and perfusion mismatch. Moreover, in alveolar sacs, an environment able to foster bacterial and fungal superinfections can be established, as 
demonstrated in several autopsies [93]. Secondly, bronchopneumonia is often caused by Pseudomonas aeruginosa, sp., Aspergillus sp., and cytomegalovirus [93,100].

Lung injury can sometimes be diagnosed and followed-up using X-ray and CT imaging, even if several studies have suggested that radiological features can underline histological alterations [101,102]. In addition, SARS-CoV-2 lung injury does not always show typical and defined pictures. However, the imaging role in the diagnosis and assessment of virusinduced injury is still very important [103]. Lung consolidation and ground-glass opacities at X-ray/CT imaging represent the most common path of COVID-19 infection [104], sometimes accompanied by reticular opacities. Moreover, multifocal airspace can be pointed out in COVID-19 pneumonia, frequently in a bilateral and basal distribution. Peripheral lung engagement is one of the most specific "pieces" of radiological evidence of SARSCoV-2 infection, although other inflammatory processes can lead to multifocal or confluent injuries [104].

\subsection{Cardiovascular System}

SARS-CoV-2, in addition to respiratory complications, induces alterations in the cardiovascular system. In fact, numerous studies have shown a link between COVID-19 and cardiovascular complications such as arterial hypertension, heart failure, myocardial infarction, myocarditis, arrhythmias, coagulopathy, venous thromboembolism, and DIC [105]. Clinically, cardiovascular symptoms can present as an initial manifestation or appear later. In a study by Kui et al., it was observed that $7 \%$ of COVID- 19 subjects experienced heart palpitations as an initial symptom [106]. In another study, $16 \%$ of the patients underwent different degrees of myocardial damage [107].

In this context, subjects with previous cardiovascular diseases have an increased risk of severity and mortality in the case of SARS-CoV-2 infection due to the massive presence of ACE2 receptors in the cardiovascular system [108]. Indeed, the measurement of plasma angiotensin peptides and plasma ACE2 levels may be useful in evaluating treatment efficacy and the status of the renin-angiotensin-aldosterone system in COVID-19 patients [109].

The etiology of ACE2-dependent cardiovascular damage induced by COVID-19 appears to be complex. Metabolic alterations, hypoxia, and inflammation of the myocardium play an important role in the pathophysiology of myocardial damage and arrhythmic complications. The virus enters the cardiovascular cells through ACE2 receptors. In fact, the increased expression of ACE2 receptors in the cardiovascular system is one of the determinants of infection, causing systemic inflammation and damage to heart tissue. In a postmortem study conducted by Lindner et al. on 39 patients who died from SARS-CoV-2 infection, it was demonstrated that the virus is not localized exclusively in cardiomyocytes but also in interstitial cells or macrophages that invade myocardial tissue [110]. Several epidemiological studies have demonstrated that viral RNA infection induced cardiomyocyte apoptosis, activating the innate immune response, which, through the production of inflammatory cytokines, destabilized the coronary plaques and caused left ventricular insufficiency [111,112]. Furthermore, the role of hyperactivated T-lymphocytes in cardiomyocytic damage has been demonstrated. In fact, there is an immunological dysregulation characterized by inflammation and a "cytokine storm" that contributes to damage on the cardiovascular level [113].

Patients with cardiovascular complications showed significant increases in cardiac troponin I, N-terminal pro-B-type natriuretic peptide, IL-6 and other cytokines (like IL-1B, IL-1RA, IL-7, IL-8, IL-9, IL-10, and TNF- $\alpha$ ), C-X-C motif ligand 10 (CXCL10), chemokine ligand 2 (CCL2), and granulocyte-macrophage colony-stimulating factor (GM-CSF) in the bloodstream [114,115].

Coagulopathy associated with SARS-CoV-2 is revealed mainly as organ damage, while hemorrhages are rare. In addition, it is characterized by an increase in D-dimer and the degradation products of fibrin/fibrinogen. Alterations in hemostatic biomarkers indicate that COVID-19 is characterized by massive fibrin formation. This suggests that 
hyperfibrinolysis secondary to the coagulation process is the primary manifestation of COVID-19-associated coagulopathy [116].

Instead, the prolongation of prothrombin time (PT) and partial thromboplastin time and the reduction of antithrombin activity induce, less frequently, thrombocytopenia in COVID-19 patients compared to other septic DIC patients. In a meta-analysis conducted by Lippi et al. [117], thrombocytopenia has been shown to be associated with an increased risk of disease severity and mortality in COVID-19. Furthermore, thrombocytosis has been found in moderately severe cases and long-term hospitalized patients [118]. Therefore, it might be that thrombocytosis and thrombocytopenia are associated with different stages or severity of the disease.

The mechanisms underlying coagulopathy are not yet fully understood. It is hypothesized that the main causes of coagulation abnormalities are the excessive production of proinflammatory cytokines, increased levels of damage-associated molecular patterns (DAMP), stimulation of cell death mechanisms, and vascular endothelial damage [1]. The increase and dysregulation of inflammatory cytokines and chemokines induce the recruitment of immune cells in infected tissues, which have a defensive role in the host but can also cause damage.

Wu et al. [119] analyzed the relationship between coagulopathy and the development of ARDS in COVID-19 patients, demonstrating that coagulopathy occurs mainly in critically ill patients. Therefore, continuous monitoring of D-dimer and PT is crucial for patient management.

Indeed, the incidence of thrombosis and thromboembolic consequences is more frequent in intensive care COVID-19 patients rather than in non-COVID-19 septic patients in intensive care [120].

\subsection{Kidney and Urinary Tract}

Among the SARS-CoV-2 target organs, the urinary system may also be involved. In particular, in the most critically ill COVID-19 patients, cases of AKI have been reported, with an incidence ranging from $0.9 \%$ to $29 \%$ of total cases [121]. In detail, the incidence of AKI is more than $20 \%$ in hospitalized patients and more than $50 \%$ in intensive care patients [122,123]. In addition, an interesting study reported that $60 \%$ of hospitalized patients showed proteinuria and $48 \%$ showed hematuria [124].

From autopsy reports performed in the city of Wuhan, microscopic examination of the kidney revealed that AKI was induced by acute tubular necrosis, characterized by lumen dilation, vascular degeneration, and alteration of the tubular epithelium [121,125].

It has been hypothesized that the physiopathological mechanisms underlying the onset of AKI are multifactorial [122] and divisible into direct and indirect ones. Recent studies have shown that the virus can directly induce histopathological alterations in the kidney. This hypothesis was supported by a postmortem study showing the presence of viral particles at the level of the tubular epithelium and podocytes, detected by electron microscopy [126,127]. Several studies have demonstrated that the virus enters the renal parenchyma through binding to ACE2, TMPRSS2, and catepsine-1 (CTSI) receptors that are highly expressed at the kidney level. An additional risk factor is the induction of endothelial dysfunction by SARS-CoV-2, interconnected with coagulopathy, typical of COVID-19 patients. Both of the alterations mentioned above are related to the direct viral activation of the complement. In addition, kidney involvement can also be explained by the acute inflammatory state related to SARS-CoV-2 infection, defined as a "cytokine storm". The increase in cytokines is not constant in all SARS-CoV-2 patients; in fact, it has been hypothesized that they have moderately increased cytokines compared to what is observed in other coronavirus-induced respiratory infections (such as SARS and MERS) [128-130].

Indirect mechanisms of renal involvement are partly correlated with clinical manifestations due to infection, i.e., they arise if patients have gastrointestinal symptoms (such as diarrhea and, more rarely, vomiting) and fever, which induce a reduction of volemia, with greater susceptibility to developing prerenal-AKI. At the same time, the drugs used for 
critically ill patients can be nephrotoxic; antibiotics, especially, can induce tubular damage or acute interstitial nephritis [131-133]. Sometimes the most critical COVID-19 patients may have concomitant secondary infections (e.g., bacterial or fungal) that increase the risk of secondary AKI to the septic state. Finally, it should not be neglected that patient age and basal comorbidities play a key role in the onset of AKI [134].

It should also be considered that COVID-19 patients are more susceptible to acute pyelonephritis [135]. Specifically, this association is not supported by consistent epidemiological studies. A combination of SARS-CoV-2 infection and urological symptoms, not necessarily induced by SARS-CoV-2, has been observed. This association turned out to be speculative [136]. In patients with COVID-19, initial symptoms of urological relevance such as flank pain, urinary urgency, pollakiuria, stranguria, and fever have been described [137]. Moreover, it has been hypothesized that these symptoms are attributable to viral cystitis from SARS-CoV-2, although it is not clear if the virus replicates directly in endothelial cells or if it induces endothelitis in the urinary system [138]. The debate remains open.

\subsection{Liver and Gastrointestinal Tract}

ACE2 is also highly expressed in the small and large intestines. In fact, SARS-CoV-2 was found in the cytoplasm of the epithelia of the duodenum and rectum [139], while the expression of ACE2 receptors is significantly lower in the esophagus and stomach $[72,140]$. Furthermore, in esophageal and gastric mucosa, there is a lower expression of TMPRSS2 compared to intestinal mucosa [141]. From a diagnostic point of view, stool examination showed the presence of SARS-CoV-2 using the reverse transcriptase-polymerase chain reaction (RT-PCR) technique [142].

Clinically, COVID-19 patients have also shown gastrointestinal symptoms such as vomiting, abdominal pain, and diarrhea, as highlighted by several studies [142-144]. In fact, in a study conducted by Han et al. [145], it was observed that $19 \%$ of patients had diarrhea as the first symptom of the disease, and $62 \%$ had fever and enteric symptoms. Furthermore, the authors found that patients with digestive symptoms took a longer period of time between the symptom onset and viral clearance.

During the COVID-19 pandemic, gastrointestinal emergencies have been rare. Some patients have experienced severe diarrhea, with electrolyte disturbances or bloody and inflammatory diarrhea, during or before the onset of pulmonary symptoms $[146,147]$.

In addition, cases of acute pancreatitis and acute cholecystitis induced by SARS-CoV-2 have been reported [148-150]. The involvement of the gallbladder and biliary tract in SARS-CoV-2 infection can be explained by the presence of ACE2 receptors on the epithelial cells of the gallbladder and bile ducts.

Gastrointestinal bleeding due to COVID-19 is not very common [151]. In fact, in a study conducted by Yang et al., only $4 \%$ of the patients experienced gastrointestinal bleeding [152]. Often, the cause of the bleeding is not identified because endoscopic diagnostic procedures were not performed and patients were treated conservatively [153]. In a study conducted by Massironi et al., endoscopy showed herpetic-like erosions of gastrointestinal mucosa and ulcers with positive biopsies for SARS-CoV-2 [154]. In the case of lower gastrointestinal bleeding, it is probably caused by ischemia related to thrombotic dysfunction, resulting from systemic inflammation or a state of hypoperfusion [155]. The increased levels of D-dimer and fibrinogen present in COVID-19 patients may be responsible not only for pulmonary and peripheral thrombotic phenomena but also intestinal hypercoagulability leading to ischemic events [156,157].

Liver damage is usually associated with low albumin values and increased ALT, AST, and bilirubin levels; meanwhile, high elevated gamma-glutamyl transferase (GGT) levels are observed only in severe cases [144]. On the other hand, alkaline-phosphating (AKP) levels remain unchanged regardless of infection severity [158].

Furthermore, the degree of liver damage seems to be related to disease severity [158]. ACE2 receptors are widely distributed in liver tissue, particularly in bile duct cells and hepatocytes. The biliary duct cells have a high number of ACE2 receptors on their surface, 
suggesting that hepatocytes are not directly involved in liver damage [158]. The presence of viral load in liver cells was confirmed using the RT-PCR technique, but it was lower compared with biliary duct cells [158]. The imaging and histopathological alterations of COVID-19 patients also include low lobular and portal activity and microvascular steatosis.

Further studies would need to show whether liver damage is solely due to virus entry or whether there is a hepatotoxic effect linked to antiviral drugs.

\subsection{Nervous System}

Numerous studies have shown that beta-coronaviruses, in particular SARS-CoV, MERS-Cov, and the coronavirus responsible for porcine hemagglutinating encephalomyelitis (HEV), are able to invade the CNS (Figure 4) [159-162].

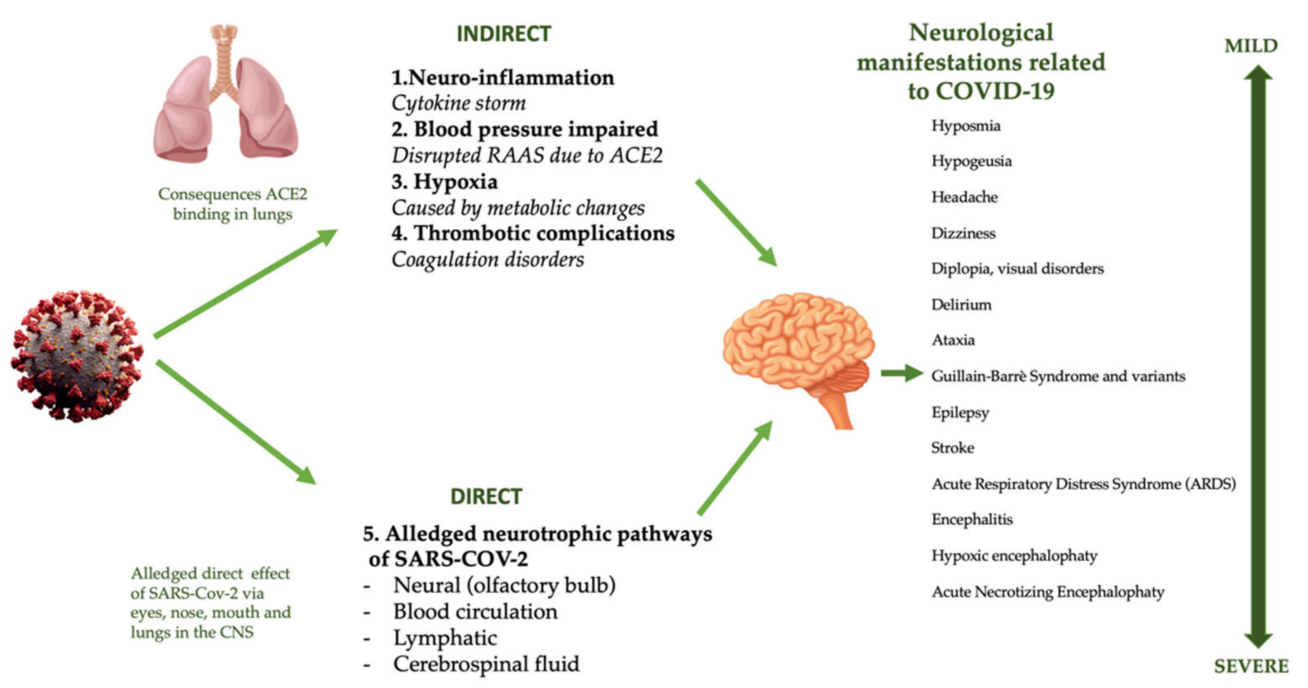

Figure 4. Direct and indirect mechanisms of COVID-19 CNS damage. Abbreviations: ACE2, angiotensin-converting enzyme 2; CNS, central nervous system; RAAS, renin-angiotensin aldosterone system; SARS-CoV-2, severe acute respiratory syndrome coronavirus 2.

The exact mechanism by which SARS-CoV-2 affects the nervous system is not yet fully understood [163]. Overall, the expression of ACE2 in the nervous system is low, so low colonization by SARS-CoV-2 in the CNS and the liver should be assumed [164]. In the CNS, ACE2 receptors are expressed mostly on neurons and glial cells, through which the virus is able to penetrate those cells [83]. The virus colonizes the CNS through different ACE2-binding pathways. The first one is represented by the binding of SARS-CoV-2 with ACE2 receptors on the capillary endothelium, which causes vascular dysfunction, rupture of the blood-brain barrier, and brain invasion [165]. The second mechanism is represented by a direct hematogenous route at the level of circumventricular pathways, such as the subfornical organ, the paraventricular nucleus, the nucleus of the solitary tract, and in the ventrorostral medullary area. These areas are not "protected" by the blood-brain barrier and are rich in ACE2 [166], favorable conditions for the entry into the CNS of any neurotrophic virus [167].

A further mechanism is represented by via transsynaptic signaling, as reported by Lì et al. The authors conducted a study on rats, in which low concentrations of SARS-CoV-2, deposited in the nasal mucosa, accessed the brain through cranial nerves - mainly the olfactory one, invading the CNS and, in particular, the thalamus and brainstem [159,168,169]. These data highlight the marked neurotropism of SARS-CoV-2, subsequently confirmed through (i) autopsy examinations that detected tissue edema, neuronal necrosis, neuroglia alterations; (ii) radiological analysis showing signs of necrotizing encephalitis at the thalamic level and of the brainstem; (iii) fluid cerebrospinal analysis (CSF), with positive genotyping of SARS-CoV-2 in cases of encephalitis [170-172]. 
An additional alternative mechanism of virus penetration into brain tissue is represented by trigeminal and vagal pathways [173-175]. The presence of the virus in the brainstem involves viral penetration into the nucleus of the solitary tract, in the baroreceptor and chemoreceptor centers implied in the regulation of respiration and cardiocirculatory functions. A possible retrograde invasion from the brainstem to the lung has also been speculated, indicating a vicious circle that is able to support and aggravate respiratory insufficiency [159].

Clinically, neurological manifestations may precede the appearance of classic respiratory symptoms by a few days [176]; these can be grouped into three categories: (i) central nervous system symptoms (such as dizziness, headache, vascular-cerebral disease, seizures, altered consciousness), (ii) peripheral nervous system symptoms (such as hyposmia, hypogeusia, visual impairment, neuropathic pain, Guillain-Barre syndrome and its variants), (iii) skeletal-muscle injury symptoms (such as myalgia, fatigue, increased levels of muscle enzymes) [176].

Up to date, the most frequent neurological symptoms reported by COVID-19 patients are hyposmia and hypogeusia, continuous headaches, a generalized confusional state, and psychotic disorders.

Other neurological characteristic symptoms are delirium and cognitive deficits. The latter are caused by systemic inflammation associated with prolonged hypoxia, which induces uncontrolled neuroinflammation, representing a pivotal factor of hippocampus and cortical area (centers of cognitive function) damage [177].

The "cytokines storm" characteristic of COVID-19 patients [1] induces immune dysregulation and neurotoxicity [176]. This systemic inflammatory cascade is characterized by a massive release of interleukins and chemokines, which causes a significant rupture of the blood-brain barrier and is responsible for subsequent neuroinflammatory processes $[178,179]$. Furthermore, the breaking of the blood-brain barrier aggravates neuroinflammation through the activation of TLRs on the microglia by ILs, which then recruit astrocytes, monocytes, dendritic cells, and lymphocytes that have already invaded the CNS [180]. All these cells enhance the neuroinflammatory process, as evidenced by glial cell hypertrophy and by neuronal element death [181,182]. In physiological conditions, the glial cells constantly monitor the cerebral microenvironment and, through the release of cytotoxic substances such as reactive oxygen species, proteinases, and inflammatory mediators, try to limit the spread of infection [183]. This hypothesis of "uncontrolled neuroinflammation" is supported by the fact that the average age of COVID-19 symptomatic patients is over 60 years old [74]. Several studies have reported that patients aged over 60 could already present low-grade brain aging, so that the SARS-CoV-2 infection may worsen the pre-existing clinical picture [181,184,185].

The hypoxia induced by COVID-19 stimulates several transcription factors-first of all, $\mathrm{Nf}-\mathrm{k} \beta$, and then, hypoxia-inducible factor (HIF). They, in turn, activate genes that regulate the transcription of numerous inflammatory messengers, causing further gliosis [186]. An additional worsening of neuroinflammatory processes is certainly determined by the physical and psychological stress induced by the pandemic [187].

Usually, antiviral immunity can effectively antagonize viral diffusion through the activation of glial cells and the entry of sentinel T-cells into the brain [188]. Unfortunately, in COVID-19 disease, the marked lymphopenia and the possible dysfunction of glial cells, which, in turn, are infected, can cause reduced activation of the defense mechanism, resulting in longer agent persistence in the CNS [13].

Moreover, COVID-19 can cause an increase of other inflammatory markers, such as Ddimer and calcitonin gene-related peptide (CGRP), which play key roles in the pathogenesis of cerebrovascular events and migraine, respectively [189-193]. The last mechanism may be represented by cerebral hypoxia/anoxia, neuronal edema secondary to DAD, and interstitial lung involvement [165]. It is also important to highlight that a large number of patients who experienced both neuroinflammatory symptoms and ARDS (not particularly severe) can continue to present, over time, cognitive impairments [194]. 


\section{Conclusions}

um-PEA would seem to have numerous healthy effects on different organs and systems, thanks to its various mechanisms acting on inflammation, pain and improving a wide variety of signs and symptoms of both chronic and acute pathological conditions, among them COVID-19 [53]. In this perspective, as um-PEA is safe, endogenous, and nontoxic, its supplementation, aiming at the modulation of the immune system, could represent an addon therapy to traditional pharmacological drugs for COVID-19 patients [20,22]. Currently, Food and Drug Administration Agency (FDA) has given permission the ongoing phase 2 clinical trial to assess um-PEA effects on hospitalized COVID-19 patients [59,195]. In Italy, a clinical study is in progress (approved by the Ethical Committee of Policlinico Tor Vergata Hospital, Rome, protocol number R.S. 73.20) to evaluate the possible beneficial physiological effects of um-PEA on inflammatory indices in asymptomatic and paucisymptomatic COVID-19 patients.

Author Contributions: Conceptualization, A.N., M.A., and G.M. writing-original draft preparation A.N., M.A., G.M., M.D.L., A.P.Z., D.P., C.G., A.P., G.P., and F.D.D.; writing-review and editing, A.R., C.D., A.M., N.B.M., and N.D.D.; visualization, C.G.; supervision, A.N., M.A., and G.M. All authors have read and agreed to the published version of the manuscript.

Funding: This research received no external funding.

Institutional Review Board Statement: Not applicable.

Informed Consent Statement: Not applicable.

Acknowledgments: We are indebted to Alessandro Cavaliere for his scientific support. The authors gratefully acknowledge the financial support of Regione Lazio (IR approved by Giunta Regionale n. G10795, 7 August 2019 published by BURL n. 6927 August 2019), ISIS@MACH (I), and ISIS Neutron and Muon Source (UK) of Science and Technology Facilities Council (STFC); the financial support of Consiglio Nazionale delle Ricerche within CNR-STFC Agreement 2014-2020 (N 3420), concerning collaboration in scientific research at the ISIS Neutron and Muon Source (UK) of Science and Technology Facilities Council (STFC), is gratefully acknowledged.

Conflicts of Interest: The authors declare no conflict of interest.

\section{Abbreviations List}

ACE2
AKI
AKP
ALT
ARDS
AST
CCL2
CGRP
CNS
COVID-19
COX-2
CSF
CTSI
CXCL10
DAD
DIC
FDA
GGT
GM-CSF
GPR55
HEV
HIF

Angiotensin-Converting Enzyme

Acute Kidney Injury

Alkaline Phosphating

Alanine Aminotransferase

Acute Respiratory Distress Syndrome

Aspartate Aminotransferase

Chemokine Ligand 2

Calcitonin Gene-Related Peptide

Central Nervous System

Coronavirus Disease-19

Cyclooxygenase-2

Fluid Cerebrospinal Analysis

Catepsine-1

C-X-C motif ligand (CXCL)10

Diffuse Alveolar Damage

Disseminated Intravascular Coagulation

Food and Drug Administration Agency

Gamma-Glutamyl Transferase

Granulocyte-Macrophage Colony Stimulating Factor

G-Protein-Coupled Receptors 55

Porcine Hemagglutinating Encephalomyelitis

Hypoxia-Inducible Factor 


IKCa
IL
iNOS
MERS-CoV
MOF
NBC
Nf-k $\beta$
PEA
PG
PPAR $\alpha$
PT
RT-PCR
SARS-CoV-2
TLRs
TMPRSS2
TNF- $\alpha$
TRP
um-PEA

High Conductance Potassium Channels

Interleukin

Inducible Nitric Oxide Synthase

Middle East Respiratory Syndrome Coronavirus Infection

Multiorgan Failure

Natural Bioactive Compound

Nuclear Factor Kappa-Light-Chain-Enhancer of Activated B Cells

Palmitoylethanolamide

Prostaglandin

Peroxisome Proliferator-Activated Receptor $\alpha$

Prothrombin Time

Reverse Transcriptase Polymerase Chain Reaction

Severe Acute Respiratory Syndrome Coronavirus-2

Toll-Like Receptors

Transmembrane Serine Protease 2

Tumor Necrosis Factor-A

Transient Receptor Potential

Ultramicronized Palmitoylethanolamide

\section{References}

1. Huang, C.; Wang, Y.; Li, X.; Ren, L.; Zhao, J.; Hu, Y.; Zhang, L.; Fan, G.; Xu, J.; Gu, X.; et al. Clinical features of patients infected with 2019 novel coronavirus in Wuhan, China. Lancet 2020, 395, 497-506. [CrossRef]

2. Noce, A.; Santoro, M.L.; Marrone, G.; D'Agostini, C.; Amelio, I.; Duggento, A.; Tesauro, M.; di Daniele, N. Serological determinants of COVID-19. Biol. Direct 2020, 15, 21. [CrossRef] [PubMed]

3. WHO. Coronavirus Disease (COVID-19) Pandemic. Available online: https://www.who.int/emergencies/diseases/ novel-coronavirus-2019?gclid=CjwKCAiAgJWABhArEi-wAmNVTB5aM0iEjG_rAywBeJGuiMooqqGeEMk1ecaYH6Jmy8 LNLAZTQJL5U9RoCS2gQAvD_BwE (accessed on 30 January 2021).

4. $\quad$ Fu, L.; Wang, B.; Yuan, T.; Chen, X.; Ao, Y.; Fitzpatrick, T.; Li, P.; Zhou, Y.; Lin, Y.F.; Duan, Q.; et al. Clinical characteristics of coronavirus disease 2019 (COVID-19) in China: A systematic review and meta-analysis. J. Infect. 2020, 80, 656-665. [CrossRef] [PubMed]

5. Ashraf, O.; Virani, A.; Cheema, T. COVID-19: An update on the epidemiological, clinical, preventive, and therapeutic management of 2019 novel coronavirus disease. Crit. Care Nurs. Q. 2021, 44, 128-137. [CrossRef]

6. Lai, C.C.; Ko, W.C.; Lee, P.I.; Jean, S.S.; Hsueh, P.R. Extra-respiratory manifestations of COVID-19. Int. J. Antimicrob. Agents 2020, 56, 106024. [CrossRef]

7. Tahir, F.; Arif, T.B.; Ahmed, J.; Malik, F.; Khalid, M. Cardiac manifestations of coronavirus disease 2019 (COVID-19): A comprehensive review. Cureus 2020, 12, e8021. [CrossRef]

8. Rokkas, T. Gastrointestinal involvement in COVID-19: A systematic review and meta-analysis. Ann. Gastroenterol. 2020, 33, 355-365. [CrossRef]

9. Cheong, J.; Bartell, N.; Peeraphatdit, T.; Mosli, M.; Al-Judaibi, B. Gastrointestinal and liver manifestations of COVID-19. Saudi J. Gastroenterol. 2020, 26, 226-232. [CrossRef]

10. Daneshgaran, G.; Dubin, D.P.; Gould, D.J. Cutaneous manifestations of COVID-19: An evidence-based review. Am. J. Clin. Dermatol. 2020, 21, 627-639. [CrossRef]

11. Vaira, L.A.; Salzano, G.; Deiana, G.; de Riu, G. Anosmia and ageusia: Common findings in COVID-19 patients. Laryngoscope 2020, 130, 1787. [CrossRef]

12. Ahmad, I.; Rathore, F.A. Neurological manifestations and complications of COVID-19: A literature review. J. Clin. Neurosci. 2020, 77, 8-12. [CrossRef]

13. Pedersen, S.F.; Ho, Y.C. SARS-CoV-2: A storm is raging. J. Clin. Investig. 2020, 130, 2202-2205. [CrossRef]

14. Kolhe, N.V.; Fluck, R.J.; Selby, N.M.; Taal, M.W. Acute kidney injury associated with COVID-19: A retrospective cohort study. PLoS Med. 2020, 17, e1003406. [CrossRef]

15. Esakandari, H.; Nabi-Afjadi, M.; Fakkari-Afjadi, J.; Farahmandian, N.; Miresmaeili, S.M.; Bahreini, E. A comprehensive review of COVID-19 characteristics. Biol. Proc. Online 2020, 22, 19. [CrossRef]

16. Petrosino, S.; Iuvone, T.; di Marzo, V. N-palmitoyl-ethanolamine: Biochemistry and new therapeutic opportunities. Biochimie 2010, 92, 724-727. [CrossRef]

17. Petrosino, S.; di Marzo, V. The pharmacology of palmitoylethanolamide and first data on the therapeutic efficacy of some of its new formulations. Br. J. Pharmacol. 2017, 174, 1349-1365. [CrossRef]

18. Lo Verme, J.; Fu, J.; Astarita, G.; la Rana, G.; Russo, R.; Calignano, A.; Piomelli, D. The nuclear receptor peroxisome proliferatoractivated receptor-alpha mediates the anti-inflammatory actions of palmitoylethanolamide. Mol. Pharmacol. 2005, 67, 15-19. [CrossRef] 
19. Gabrielsson, L.; Mattsson, S.; Fowler, C.J. Palmitoylethanolamide for the treatment of pain: Pharmacokinetics, safety and efficacy. Br. J. Clin. Pharmacol. 2016, 82, 932-942. [CrossRef]

20. Gatti, A.; Lazzari, M.; Gianfelice, V.; di Paolo, A.; Sabato, E.; Sabato, A.F. Palmitoylethanolamide in the treatment of chronic pain caused by different etiopathogenesis. Pain Med. 2012, 13, 1121-1130. [CrossRef]

21. Kuehl, F.A.; Jacob, T.A.; Ganley, O.H.; Ormond, R.E.; Meisinger, M.A.P. The identification of n-(2-hydroxyethyl)-palmitamide as a naturally occurring anti-inflammatory agent. J. Am. Chem. Soc. 1957, 79, 5577-5578. [CrossRef]

22. Paladini, A.; Fusco, M.; Cenacchi, T.; Schievano, C.; Piroli, A.; Varrassi, G. Palmitoylethanolamide, a special food for medical purposes, in the treatment of chronic pain: A pooled data meta-analysis. Pain Physician 2016, 19, 11-24.

23. Cordaro, M.; Cuzzocrea, S.; Crupi, R. An update of palmitoylethanolamide and luteolin effects in preclinical and clinical studies of neuroinflammatory events. Antioxidants (Basel) 2020, 9, 216. [CrossRef]

24. Kahlich, R.; Klima, J.; Cihla, F.; Frankova, V.; Masek, K.; Rosicky, M.; Matousek, F.; Bruthans, J. Studies on prophylactic efficacy of N-2-hydroxyethyl palmitamide (Impulsin) in acute respiratory infections. Serologically controlled field trials. J. Hyg. Epidemiol. Microbiol. Immunol. 1979, 23, 11-24.

25. Hesselink, J.M.K.; de Boer, T.; Witkamp, R.F. Palmitoylethanolamide: A natural body-own anti-inflammatory agent, effective and safe against influenza and common cold. Int. J. Inflam. 2013, 2013, 151028. [CrossRef]

26. Vacondio, F.; Bassi, M.; Silva, C.; Castelli, R.; Carmi, C.; Scalvini, L.; Lodola, A.; Vivo, V.; Flammini, L.; Barocelli, E.; et al. Amino acid derivatives as palmitoylethanolamide prodrugs: Synthesis, in vitro metabolism and in vivo plasma profile in rats. PLoS ONE 2015, 10, e0128699. [CrossRef]

27. Impellizzeri, D.; Bruschetta, G.; Cordaro, M.; Crupi, R.; Siracusa, R.; Esposito, E.; Cuzzocrea, S. Micronized/ultramicronized palmitoylethanolamide displays superior oral efficacy compared to nonmicronized palmitoylethanolamide in a rat model of inflammatory pain. J. Neuroinflamm. 2014, 11, 136. [CrossRef]

28. Petrosino, S.; Schiano Moriello, A.; Cerrato, S.; Fusco, M.; Puigdemont, A.; de Petrocellis, L.; di Marzo, V. The anti-inflammatory mediator palmitoylethanolamide enhances the levels of 2-arachidonoyl-glycerol and potentiates its actions at TRPV1 cation channels. Br. J. Pharmacol. 2016, 173, 1154-1162. [CrossRef]

29. Esposito, E.; Paterniti, I.; Mazzon, E.; Genovese, T.; di Paola, R.; Galuppo, M.; Cuzzocrea, S. Effects of palmitoylethanolamide on release of mast cell peptidases and neurotrophic factors after spinal cord injury. Brain Behav. Immun. 2011, 25, 1099-1112. [CrossRef]

30. Krystel-Whittemore, M.; Dileepan, K.N.; Wood, J.G. Mast Cell: A Multi-Functional Master Cell. Front. Immunol. 2015, 6, 620. [CrossRef]

31. Hu, Y.; Jin, Y.; Han, D.; Zhang, G.; Cao, S.; Xie, J.; Xue, J.; Li, Y.; Meng, D.; Fan, X.; et al. Mast cell-induced lung injury in mice infected with H5N1 influenza virus. J. Virol. 2012, 86, 3347-3356. [CrossRef]

32. Gralinski, L.E.; Sheahan, T.P.; Morrison, T.E.; Menachery, V.D.; Jensen, K.; Leist, S.R.; Whitmore, A.; Heise, M.T.; Baric, R.S. Complement Activation Contributes to Severe Acute Respiratory Syndrome Coronavirus Pathogenesis. mBio 2018, 9. [CrossRef] [PubMed]

33. Levi-Montalcini, R.; Skaper, S.D.; dal Toso, R.; Petrelli, L.; Leon, A. Nerve growth factor: From neurotrophin to neurokine. Trends Neurosci. 1996, 19, 514-520. [CrossRef]

34. Gigante, A.; Aquili, A.; Farinelli, L.; Caraffa, A.; Ronconi, G.; Gallenga, C.E.; Tete, G.; Kritas, S.K.; Conti, P. Sodium chromo-glycate and palmitoylethanolamide: A possible strategy to treat mast cell-induced lung inflammation in COVID-19. Med. Hypotheses 2020, 143, 109856. [CrossRef] [PubMed]

35. Kempuraj, D.; Selvakumar, G.P.; Ahmed, M.E.; Raikwar, S.P.; Thangavel, R.; Khan, A.; Zaheer, S.A.; Iyer, S.S.; Burton, C.; James, D.; et al. COVID-19, Mast Cells, Cytokine Storm, Psychological Stress, and Neuroinflammation. Neuroscientist 2020, 26, 402-414. [CrossRef]

36. Kritas, S.K.; Ronconi, G.; Caraffa, A.; Gallenga, C.E.; Ross, R.; Conti, P. Mast cells contribute to coronavirus-induced inflammation: New anti-inflammatory strategy. J. Biol. Regul. Homeost. Agents 2020, 34, 9-14. [CrossRef]

37. Magadum, A.; Engel, F.B. PPARbeta/delta: Linking Metabolism to Regeneration. Int. J. Mol. Sci. 2018, 19, 2013. [CrossRef]

38. Mazzari, S.; Canella, R.; Petrelli, L.; Marcolongo, G.; Leon, A. N-(2-hydroxyethyl)hexadecanamide is orally active in reducing edema formation and inflammatory hyperalgesia by down-modulating mast cell activation. Eur. J. Pharmacol. 1996, 300, 227-236. [CrossRef]

39. Roviezzo, F.; Rossi, A.; Caiazzo, E.; Orlando, P.; Riemma, M.A.; Iacono, V.M.; Guarino, A.; Ialenti, A.; Cicala, C.; Peritore, A.; et al. Palmitoylethanolamide Supplementation during Sensitization Prevents Airway Allergic Symptoms in the Mouse. Front. Pharmacol. 2017, 8, 857. [CrossRef]

40. Del Giorno, R.; Skaper, S.; Paladini, A.; Varrassi, G.; Coaccioli, S. Palmitoylethanolamide in Fibromyalgia: Results from Prospective and Retrospective Observational Studies. Pain Ther. 2015, 4, 169-178. [CrossRef]

41. Fusco, R.; Cordaro, M.; Genovese, T.; Impellizzeri, D.; Siracusa, R.; Gugliandolo, E.; Peritore, A.F.; D’Amico, R.; Crupi, R.; Cuzzocrea, S.; et al. Adelmidrol: A New Promising Antioxidant and Anti-Inflammatory Therapeutic Tool in Pulmonary Fibrosis. Antioxidants (Basel) 2020, 9, 601. [CrossRef]

42. Fusco, M.; Skaper, S.D.; Coaccioli, S.; Varrassi, G.; Paladini, A. Degenerative Joint Diseases and Neuroinflammation. Pain Pract. 2017, 17, 522-532. [CrossRef] 
43. Iannotti, F.A.; di Marzo, V.; Petrosino, S. Endocannabinoids and endocannabinoid-related mediators: Targets, metabolism and role in neurological disorders. Prog. Lipid Res. 2016, 62, 107-128. [CrossRef]

44. Romero, T.R.; Duarte, I.D. N-palmitoyl-ethanolamine (PEA) induces peripheral antinociceptive effect by ATP-sensitive K+-channel activation. J. Pharmacol. Sci. 2012, 118, 156-160. [CrossRef]

45. Lowin, T.; Apitz, M.; Anders, S.; Straub, R.H. Anti-inflammatory effects of N-acylethanolamines in rheumatoid arthritis synovial cells are mediated by TRPV1 and TRPA1 in a COX-2 dependent manner. Arthritis Res. Ther. 2015, 17, 321. [CrossRef]

46. D'Agostino, G.; la Rana, G.; Russo, R.; Sasso, O.; Iacono, A.; Esposito, E.; Raso, G.M.; Cuzzocrea, S.; Loverme, J.; Piomelli, D.; et al. Central administration of palmitoylethanolamide reduces hyperalgesia in mice via inhibition of NF-kappaB nuclear signalling in dorsal root ganglia. Eur. J. Pharmacol. 2009, 613, 54-59. [CrossRef]

47. Pertwee, R.G. GPR55: A new member of the cannabinoid receptor clan? Br. J. Pharmacol. 2007, 152, 984-986. [CrossRef]

48. Sasso, O.; la Rana, G.; Vitiello, S.; Russo, R.; D’Agostino, G.; Iacono, A.; Russo, E.; Citraro, R.; Cuzzocrea, S.; Piazza, P.V.; et al. Palmitoylethanolamide modulates pentobarbital-evoked hypnotic effect in mice: Involvement of allopregnanolone biosynthesis. Eur. Neuropsychopharmacol. 2010, 20, 195-206. [CrossRef]

49. Artukoglu, B.B.; Beyer, C.; Zuloff-Shani, A.; Brener, E.; Bloch, M.H. Efficacy of Palmitoylethanolamide for Pain: A Meta-Analysis. Pain Physician 2017, 20, 353-362.

50. Richardson, J.D.; Vasko, M.R. Cellular mechanisms of neurogenic inflammation. J. Pharmacol. Exp. Ther. 2002, 302, 839-845. [CrossRef]

51. De Petrocellis, L.; Davis, J.B.; di Marzo, V. Palmitoylethanolamide enhances anandamide stimulation of human vanilloid VR1 receptors. FEBS Lett. 2001, 506, 253-256. [CrossRef]

52. Ambrosino, P.; Soldovieri, M.V.; Russo, C.; Taglialatela, M. Activation and desensitization of TRPV1 channels in sensory neurons by the PPARalpha agonist palmitoylethanolamide. Br. J. Pharmacol. 2013, 168, 1430-1444. [CrossRef]

53. Rankin, L.; Fowler, C.J. The Basal Pharmacology of Palmitoylethanolamide. Int. J. Mol. Sci. 2020, 21, 7942. [CrossRef]

54. Sharir, H.; Console-Bram, L.; Mundy, C.; Popoff, S.N.; Kapur, A.; Abood, M.E. The endocannabinoids anandamide and virodhamine modulate the activity of the candidate cannabinoid receptor GPR55. J. Neuroimmune Pharmacol. 2012, 7, 856-865. [CrossRef]

55. Ryberg, E.; Larsson, N.; Sjogren, S.; Hjorth, S.; Hermansson, N.O.; Leonova, J.; Elebring, T.; Nilsson, K.; Drmota, T.; Greasley, P.J. The orphan receptor GPR55 is a novel cannabinoid receptor. Br. J. Pharmacol. 2007, 152, 1092-1101. [CrossRef]

56. Lauckner, J.E.; Jensen, J.B.; Chen, H.Y.; Lu, H.C.; Hille, B.; Mackie, K. GPR55 is a cannabinoid receptor that increases intracellular calcium and inhibits M current. Proc. Natl. Acad. Sci. USA 2008, 105, 2699-2704. [CrossRef]

57. Karamloo, F.; Konig, R. SARS-CoV-2 immunogenicity at the crossroads. Allergy 2020, 75, 1822-1824. [CrossRef]

58. Esposito, G.; Capoccia, E.; Turco, F.; Palumbo, I.; Lu, J.; Steardo, A.; Cuomo, R.; Sarnelli, G.; Steardo, L. Palmitoylethanolamide improves colon inflammation through an enteric glia/toll like receptor 4-dependent PPAR-alpha activation. Gut 2014, 63, 1300-1312. [CrossRef]

59. Pesce, M.; Seguella, L.; Cassarano, S.; Aurino, L.; Sanseverino, W.; Lu, J.; Corpetti, C.; del Re, A.; Vincenzi, M.; Sarnelli, G.; et al. Phytotherapics in COVID19: Why palmitoylethanolamide? Phytother. Res. 2020, 1-9. [CrossRef]

60. Schonrich, G.; Raftery, M.J.; Samstag, Y. Devilishly radical NETwork in COVID-19: Oxidative stress, neutrophil extracellular traps (NETs), and T cell suppression. Adv. Biol. Regul. 2020, 77, 100741. [CrossRef]

61. Wong, S.H.; Lui, R.N.; Sung, J.J. Covid-19 and the digestive system. J. Gastroenterol. Hepatol. 2020, 35, 744-748. [CrossRef]

62. Alomari, S.O.; Abou-Mrad, Z.; Bydon, A. COVID-19 and the central nervous system. Clin. Neurol. Neurosurg. 2020, $198,106116$. [CrossRef] [PubMed]

63. Couch, D.G.; Cook, H.; Ortori, C.; Barrett, D.; Lund, J.N.; O'Sullivan, S.E. Palmitoylethanolamide and Cannabidiol Prevent Inflammation-induced Hyperpermeability of the Human Gut In Vitro and In Vivo-A Randomized, Placebo-controlled, Doubleblind Controlled Trial. Inflamm. Bowel Dis. 2019, 25, 1006-1018. [CrossRef] [PubMed]

64. Raso, G.M.; Russo, R.; Calignano, A.; Meli, R. Palmitoylethanolamide in CNS health and disease. Pharmacol. Res. 2014, 86, 32-41. [CrossRef] [PubMed]

65. Raso, G.M.; Esposito, E.; Vitiello, S.; Iacono, A.; Santoro, A.; D’Agostino, G.; Sasso, O.; Russo, R.; Piazza, P.V.; Calignano, A.; et al. Palmitoylethanolamide stimulation induces allopregnanolone synthesis in C6 Cells and primary astrocytes: Involvement of peroxisome-proliferator activated receptor-alpha. J. Neuroendocrinol. 2011, 23, 591-600. [CrossRef]

66. Scuderi, C.; Bronzuoli, M.R.; Facchinetti, R.; Pace, L.; Ferraro, L.; Broad, K.D.; Serviddio, G.; Bellanti, F.; Palombelli, G.; Carpinelli, G.; et al. Ultramicronized palmitoylethanolamide rescues learning and memory impairments in a triple transgenic mouse model of Alzheimer's disease by exerting anti-inflammatory and neuroprotective effects. Transl. Psychiatry 2018, 8, 32. [CrossRef]

67. Bronzuoli, M.R.; Facchinetti, R.; Steardo, L., Jr.; Romano, A.; Stecca, C.; Passarella, S.; Steardo, L.; Cassano, T.; Scuderi, C. Palmitoylethanolamide Dampens Reactive Astrogliosis and Improves Neuronal Trophic Support in a Triple Transgenic Model of Alzheimer's Disease: In Vitro and In Vivo Evidence. Oxid Med. Cell Longev. 2018, 2018, 4720532. [CrossRef]

68. Bougarne, N.; Weyers, B.; Desmet, S.J.; Deckers, J.; Ray, D.W.; Staels, B.; de Bosscher, K. Molecular Actions of PPARalpha in Lipid Metabolism and Inflammation. Endocr. Rev. 2018, 39, 760-802. [CrossRef]

69. Scuderi, C.; Stecca, C.; Valenza, M.; Ratano, P.; Bronzuoli, M.R.; Bartoli, S.; Steardo, L.; Pompili, E.; Fumagalli, L.; Campolongo, P.; et al. Palmitoylethanolamide controls reactive gliosis and exerts neuroprotective functions in a rat model of Alzheimer's disease. Cell Death Dis. 2014, 5, e1419. [CrossRef] 
70. Grippo, A.J.; Scotti, M.A. Stress and neuroinflammation. Mod. Trends Pharm. 2013, 28, 20-32. [CrossRef]

71. Wojtowicz, S.; Strosznajder, A.K.; Jezyna, M.; Strosznajder, J.B. The Novel Role of PPAR Alpha in the Brain: Promising Target in Therapy of Alzheimer's Disease and Other Neurodegenerative Disorders. Neurochem. Res. 2020, 45, 972-988. [CrossRef]

72. Hoffmann, M.; Kleine-Weber, H.; Schroeder, S.; Kruger, N.; Herrler, T.; Erichsen, S.; Schiergens, T.S.; Herrler, G.; Wu, N.H.; Nitsche, A.; et al. SARS-CoV-2 Cell Entry Depends on ACE2 and TMPRSS2 and Is Blocked by a Clinically Proven Protease Inhibitor. Cell 2020, 181, 271-280. [CrossRef]

73. Loganathan, S.K.; Schleicher, K.; Malik, A.; Quevedo, R.; Langille, E.; Teng, K.; Oh, R.H.; Rathod, B.; Tsai, R.; SamavarchiTehrani, P.; et al. Rare driver mutations in head and neck squamous cell carcinomas converge on NOTCH signaling. Science 2020, 367, 1264-1269. [CrossRef]

74. WHO. Coronavirus Disease 2019 (COVID-19) Situation Report. Available online: https://www.who.int/docs/default-source/ coronaviruse/situation-reports/20200513-covid-19-sitrep-114.pdf?sfvrsn=17ebbbe_4 (accessed on 30 January 2021).

75. Sungnak, W.; Huang, N.; Becavin, C.; Berg, M.; Queen, R.; Litvinukova, M.; Talavera-Lopez, C.; Maatz, H.; Reichart, D.; Sampaziotis, F.; et al. SARS-CoV-2 entry factors are highly expressed in nasal epithelial cells together with innate immune genes. Nat. Med. 2020, 26, 681-687. [CrossRef]

76. Shi, Y.; Wang, Y.; Shao, C.; Huang, J.; Gan, J.; Huang, X.; Bucci, E.; Piacentini, M.; Ippolito, G.; Melino, G. COVID-19 infection: The perspectives on immune responses. Cell Death Differ. 2020, 27, 1451-1454. [CrossRef]

77. Ackermann, M.; Verleden, S.E.; Kuehnel, M.; Haverich, A.; Welte, T.; Laenger, F.; Vanstapel, A.; Werlein, C.; Stark, H.; Tzankov, A.; et al. Pulmonary Vascular Endothelialitis, Thrombosis, and Angiogenesis in Covid-19. N. Engl. J. Med. 2020, 383, 120-128. [CrossRef]

78. Tay, M.Z.; Poh, C.M.; Renia, L.; MacAry, P.A.; Ng, L.F.P. The trinity of COVID-19: Immunity, inflammation and intervention. Nat. Rev. Immunol. 2020, 20, 363-374. [CrossRef]

79. Gubernatorova, E.O.; Gorshkova, E.A.; Polinova, A.I.; Drutskaya, M.S. IL-6: Relevance for immunopathology of SARS-CoV-2. Cytokine Growth Factor Rev. 2020, 53, 13-24. [CrossRef]

80. Jacob, C.O. On the genetics and immunopathogenesis of COVID-19. Clin. Immunol. 2020, 220, 108591. [CrossRef]

81. Zhang, S.; Liu, Y.; Wang, X.; Yang, L.; Li, H.; Wang, Y.; Liu, M.; Zhao, X.; Xie, Y.; Yang, Y.; et al. SARS-CoV-2 binds platelet ACE2 to enhance thrombosis in COVID-19. J. Hematol. Oncol. 2020, 13, 120. [CrossRef]

82. Iba, T.; Levy, J.H.; Levi, M.; Thachil, J. Coagulopathy in COVID-19. J. Thromb Haemost. 2020, 18, 2103-2109. [CrossRef]

83. Baig, A.M.; Khaleeq, A.; Ali, U.; Syeda, H. Evidence of the COVID-19 Virus Targeting the CNS: Tissue Distribution, Host-Virus Interaction, and Proposed Neurotropic Mechanisms. ACS Chem. Neurosci. 2020, 11, 995-998. [CrossRef]

84. Zou, X.; Chen, K.; Zou, J.; Han, P.; Hao, J.; Han, Z. Single-cell RNA-seq data analysis on the receptor ACE2 expression reveals the potential risk of different human organs vulnerable to 2019-nCoV infection. Front. Med. 2020, 14, 185-192. [CrossRef]

85. Sinha, P.; Matthay, M.A.; Calfee, C.S. Is a “Cytokine Storm” Relevant to COVID-19? JAMA Intern. Med. 2020, $180,1152-1154$. [CrossRef]

86. McGonagle, D.; Sharif, K.; O'Regan, A.; Bridgewood, C. The Role of Cytokines including Interleukin-6 in COVID-19 induced Pneumonia and Macrophage Activation Syndrome-Like Disease. Autoimmun. Rev. 2020, 19, 102537. [CrossRef]

87. Mattiuzzi, C.; Lippi, G. Which lessons shall we learn from the 2019 novel coronavirus outbreak? Ann. Transl. Med. 2020, 8, 48. [CrossRef]

88. Renu, K.; Prasanna, P.L.; Gopalakrishnan, A.V. Coronaviruses pathogenesis, comorbidities and multi-organ damage-A review. Life Sci. 2020, 255, 117839. [CrossRef] [PubMed]

89. Hamming, I.; Timens, W.; Bulthuis, M.L.; Lely, A.T.; Navis, G.; van Goor, H. Tissue distribution of ACE2 protein, the functional receptor for SARS coronavirus. A first step in understanding SARS pathogenesis. J. Pathol. 2004, 203, 631-637. [CrossRef] [PubMed]

90. Mohamed, E.I.; Maiolo, C.; Iacopino, L.; Pepe, M.; di Daniele, N.; de Lorenzo, A. The impact of body-weight components on forced spirometry in healthy italians. Lung 2002, 180, 149-159. [CrossRef] [PubMed]

91. Wong, H.Y.F.; Lam, H.Y.S.; Fong, A.H.; Leung, S.T.; Chin, T.W.; Lo, C.S.Y.; Lui, M.M.; Lee, J.C.Y.; Chiu, K.W.; Chung, T.W.; et al. Frequency and Distribution of Chest Radiographic Findings in Patients Positive for COVID-19. Radiology 2020, 296, E72-E78. [CrossRef]

92. Cheung, O.Y.; Chan, J.W.; Ng, C.K.; Koo, C.K. The spectrum of pathological changes in severe acute respiratory syndrome (SARS). Histopathology 2004, 45, 119-124. [CrossRef]

93. Franks, T.J.; Chong, P.Y.; Chui, P.; Galvin, J.R.; Lourens, R.M.; Reid, A.H.; Selbs, E.; McEvoy, C.P.; Hayden, C.D.; Fukuoka, J.; et al. Lung pathology of severe acute respiratory syndrome (SARS): A study of 8 autopsy cases from Singapore. Hum. Pathol. 2003, 34, 743-748. [CrossRef]

94. Lee, N.; Hui, D.; Wu, A.; Chan, P.; Cameron, P.; Joynt, G.M.; Ahuja, A.; Yung, M.Y.; Leung, C.B.; To, K.F.; et al. A major outbreak of severe acute respiratory syndrome in Hong Kong. N. Engl. J. Med. 2003, 348, 1986-1994. [CrossRef]

95. Guo, Y.; Korteweg, C.; McNutt, M.A.; Gu, J. Pathogenetic mechanisms of severe acute respiratory syndrome. Virus Res. 2008, 133, 4-12. [CrossRef]

96. Thompson, M.R.; Kaminski, J.J.; Kurt-Jones, E.A.; Fitzgerald, K.A. Pattern recognition receptors and the innate immune response to viral infection. Viruses 2011, 3, 920-940. [CrossRef] 
97. Ragab, D.; Eldin, H.S.; Taeimah, M.; Khattab, R.; Salem, R. The COVID-19 Cytokine Storm; What We Know So Far. Front. Immunol. 2020, 11, 1446. [CrossRef]

98. Mitchell, W.B. Thromboinflammation in COVID-19 acute lung injury. Paediatr. Respir. Rev. 2020, 35, 20-24. [CrossRef]

99. Ding, Y.; Wang, H.; Shen, H.; Li, Z.; Geng, J.; Han, H.; Cai, J.; Li, X.; Kang, W.; Weng, D.; et al. The clinical pathology of severe acute respiratory syndrome (SARS): A report from China. J. Pathol. 2003, 200, 282-289. [CrossRef]

100. Hwang, D.M.; Chamberlain, D.W.; Poutanen, S.M.; Low, D.E.; Asa, S.L.; Butany, J. Pulmonary pathology of severe acute respiratory syndrome in Toronto. Mod. Pathol. 2005, 18, 1-10. [CrossRef]

101. Kory, P.; Kanne, J.P. SARS-CoV-2 organising pneumonia: 'Has there been a widespread failure to identify and treat this prevalent condition in COVID-19?'. BMJ Open Respir. Res. 2020, 7. [CrossRef]

102. Aiolfi, A.; Bruni, B.; Biraghi, T.; Montisci, A.; Miceli, A.; Baronio, B.; Khor, D.; Cirri, S.; Donatelli, F.; Clemente, C.; et al. Late histological findings in symptomatic COVID-19 patients: A case report. Medicine (Baltimore) 2020, 99, e21046. [CrossRef]

103. Revzin, M.V.; Raza, S.; Warshawsky, R.; D’Agostino, C.; Srivastava, N.C.; Bader, A.S.; Malhotra, A.; Patel, R.D.; Chen, K.; Kyriakakos, C.; et al. Multisystem Imaging Manifestations of COVID-19, Part 1: Viral Pathogenesis and Pulmonary and Vascular System Complications. Radiographics 2020, 40, 1574-1599. [CrossRef]

104. Chung, M.; Bernheim, A.; Mei, X.; Zhang, N.; Huang, M.; Zeng, X.; Cui, J.; Xu, W.; Yang, Y.; Fayad, Z.A.; et al. CT Imaging Features of 2019 Novel Coronavirus (2019-nCoV). Radiology 2020, 295, 202-207. [CrossRef]

105. Samidurai, A.; Das, A. Cardiovascular Complications Associated with COVID-19 and Potential Therapeutic Strategies. Int. J. Mol. Sci. 2020, 21, 6790. [CrossRef]

106. Liu, K.; Fang, Y.Y.; Deng, Y.; Liu, W.; Wang, M.F.; Ma, J.P.; Xiao, W.; Wang, Y.N.; Zhong, M.H.; Li, C.H.; et al. Clinical characteristics of novel coronavirus cases in tertiary hospitals in Hubei Province. Chin. Med. J. (Engl.) 2020, 133, 1025-1031. [CrossRef]

107. Liu, M.; He, P.; Liu, H.G.; Wang, X.J.; Li, F.J.; Chen, S.; Lin, J.; Chen, P.; Liu, J.H.; Li, C.H. Clinical characteristics of 30 medical workers infected with new coronavirus pneumonia. Zhonghua Jie He He Hu Xi Za Zhi 2020, 43, E016. [CrossRef]

108. Turner, A.J.; Hiscox, J.A.; Hooper, N.M. ACE2: From vasopeptidase to SARS virus receptor. Trends Pharmacol. Sci. 2004, 25, 291-294. [CrossRef]

109. Oudit, G.Y.; Pfeffer, M.A. Plasma angiotensin-converting enzyme 2: Novel biomarker in heart failure with implications for COVID-19. Eur. Heart J. 2020, 41, 1818-1820. [CrossRef]

110. Lindner, D.; Fitzek, A.; Brauninger, H.; Aleshcheva, G.; Edler, C.; Meissner, K.; Scherschel, K.; Kirchhof, P.; Escher, F.; Schultheiss, H.P.; et al. Association of Cardiac Infection with SARS-CoV-2 in Confirmed COVID-19 Autopsy Cases. JAMA Cardiol. 2020, 5, 1281-1285. [CrossRef]

111. Zheng, Y.Y.; Ma, Y.T.; Zhang, J.Y.; Xie, X. COVID-19 and the cardiovascular system. Nat. Rev. Cardiol. 2020, 17, 259-260. [CrossRef]

112. Blyszczuk, P. Myocarditis in Humans and in Experimental Animal Models. Front. Cardiovasc. Med. 2019, 6, 64. [CrossRef]

113. Guzik, T.J.; Mohiddin, S.A.; Dimarco, A.; Patel, V.; Savvatis, K.; Marelli-Berg, F.M.; Madhur, M.S.; Tomaszewski, M.; Maffia, P.; D'Acquisto, F; ; et al. COVID-19 and the cardiovascular system: Implications for risk assessment, diagnosis, and treatment options. Cardiovasc. Res. 2020, 116, 1666-1687. [CrossRef] [PubMed]

114. Chen, C.; Zhou, Y.; Wang, D.W. SARS-CoV-2: A potential novel etiology of fulminant myocarditis. Herz 2020, 45, $230-232$. [CrossRef] [PubMed]

115. Tajbakhsh, A.; Gheibi Hayat, S.M.; Taghizadeh, H.; Akbari, A.; Inabadi, M.; Savardashtaki, A.; Johnston, T.P.; Sahebkar, A. COVID-19 and cardiac injury: Clinical manifestations, biomarkers, mechanisms, diagnosis, treatment, and follow up. Expert Rev. Anti Infect. Ther. 2020, 19, 345-357. [CrossRef] [PubMed]

116. Tang, N.; Li, D.; Wang, X.; Sun, Z. Abnormal coagulation parameters are associated with poor prognosis in patients with novel coronavirus pneumonia. J. Thromb Haemost. 2020, 18, 844-847. [CrossRef]

117. Lippi, G.; Plebani, M.; Henry, B.M. Thrombocytopenia is associated with severe coronavirus disease 2019 (COVID-19) infections: A meta-analysis. Clin. Chim. Acta 2020, 506, 145-148. [CrossRef]

118. Qu, R.; Ling, Y.; Zhang, Y.H.; Wei, L.Y.; Chen, X.; Li, X.M.; Liu, X.Y.; Liu, H.M.; Guo, Z.; Ren, H.; et al. Platelet-to-lymphocyte ratio is associated with prognosis in patients with coronavirus disease-19. J. Med. Virol. 2020, 92, 1533-1541. [CrossRef]

119. Wu, C.; Chen, X.; Cai, Y.; Xia, J.; Zhou, X.; Xu, S.; Huang, H.; Zhang, L.; Zhou, X.; Du, C.; et al. Risk Factors Associated with Acute Respiratory Distress Syndrome and Death in Patients with Coronavirus Disease 2019 Pneumonia in Wuhan, China. JAMA Intern. Med. 2020, 180, 934-943. [CrossRef]

120. Klok, F.A.; Kruip, M.; van der Meer, N.J.M.; Arbous, M.S.; Gommers, D.; Kant, K.M.; Kaptein, F.H.J.; van Paassen, J.; Stals, M.A.M.; Huisman, M.V.; et al. Incidence of thrombotic complications in critically ill ICU patients with COVID-19. Thromb Res. 2020, 191, 145-147. [CrossRef]

121. Lynch, M.R.; Tang, J. COVID-19 and Kidney Injury. R. I. Med. J. 2020, 103, $24-28$.

122. Nadim, M.K.; Forni, L.G.; Mehta, R.L.; Connor, M.J., Jr.; Liu, K.D.; Ostermann, M.; Rimmele, T.; Zarbock, A.; Bell, S.; Bihorac, A.; et al. COVID-19-associated acute kidney injury: Consensus report of the 25th Acute Disease Quality Initiative (ADQI) Workgroup. Nat. Rev. Nephrol. 2020, 16, 747-764. [CrossRef]

123. Gupta, S.; Hayek, S.S.; Wang, W.; Chan, L.; Mathews, K.S.; Melamed, M.L.; Brenner, S.K.; Leonberg-Yoo, A.; Schenck, E.J.; Radbel, J.; et al. Factors Associated with Death in Critically Ill Patients with Coronavirus Disease 2019 in the US. JAMA Intern. Med. 2020, 180, 1436-1446. [CrossRef] 
124. Li, Z.; Wu, M.; Yao, J.; Guo, J.; Liao, X.; Song, S.; Li, J.; Duan, G.; Zhou, Y.; Wu, X.; et al. Caution on Kidney Dysfunctions of COVID-19 Patients. medRxiv 2020, 25. [CrossRef]

125. Noce, A.; Marrone, G.; Rovella, V.; Busca, A.; Gola, C.; Ferrannini, M.; di Daniele, N. Fenoldopam mesylate: A narrative review of its use in acute kidney injury. Curr. Pharm. Biotechnol. 2019, 20. [CrossRef] [PubMed]

126. Su, H.; Yang, M.; Wan, C.; Yi, L.X.; Tang, F.; Zhu, H.Y.; Yi, F.; Yang, H.C.; Fogo, A.B.; Nie, X.; et al. Renal histopathological analysis of 26 postmortem findings of patients with COVID-19 in China. Kidney Int. 2020, 98, 219-227. [CrossRef]

127. Farkash, E.A.; Wilson, A.M.; Jentzen, J.M. Ultrastructural Evidence for Direct Renal Infection with SARS-CoV-2. J. Am. Soc. Nephrol. 2020, 31, 1683-1687. [CrossRef]

128. Chien, J.Y.; Hsueh, P.R.; Cheng, W.C.; Yu, C.J.; Yang, P.C. Temporal changes in cytokine/chemokine profiles and pulmonary involvement in severe acute respiratory syndrome. Respirology 2006, 11, 715-722. [CrossRef]

129. Chu, K.H.; Tsang, W.K.; Tang, C.S.; Lam, M.F.; Lai, F.M.; To, K.F.; Fung, K.S.; Tang, H.L.; Yan, W.W.; Chan, H.W.; et al. Acute renal impairment in coronavirus-associated severe acute respiratory syndrome. Kidney Int. 2005, 67, 698-705. [CrossRef]

130. Min, C.K.; Cheon, S.; Ha, N.Y.; Sohn, K.M.; Kim, Y.; Aigerim, A.; Shin, H.M.; Choi, J.Y.; Inn, K.S.; Kim, J.H.; et al. Comparative and kinetic analysis of viral shedding and immunological responses in MERS patients representing a broad spectrum of disease severity. Sci. Rep. 2016, 6, 25359. [CrossRef]

131. Welch, H.K.; Kellum, J.A.; Kane-Gill, S.L. Drug-Associated Acute Kidney Injury Identified in the United States Food and Drug Administration Adverse Event Reporting System Database. Pharmacotherapy 2018, 38, 785-793. [CrossRef]

132. Ostermann, M.; Chawla, L.S.; Forni, L.G.; Kane-Gill, S.L.; Kellum, J.A.; Koyner, J.; Murray, P.T.; Ronco, C.; Goldstein, S.L.; ADQI 16 Workgroup. Drug management in acute kidney disease-Report of the Acute Disease Quality Initiative XVI meeting. Br. J. Clin. Pharmacol. 2018, 84, 396-403. [CrossRef]

133. Noce, A.; Fabrini, R.; Dessi, M.; Bocedi, A.; Santini, S.; Rovella, V.; Pastore, A.; Tesauro, M.; Bernardini, S.; di Daniele, N.; et al. Erythrocyte glutathione transferase activity: A possible early biomarker for blood toxicity in uremic diabetic patients. Acta Diabetol. 2014, 51, 219-224. [CrossRef] [PubMed]

134. Sargiacomo, C.; Sotgia, F.; Lisanti, M.P. COVID-19 and chronological aging: Senolytics and other anti-aging drugs for the treatment or prevention of corona virus infection? Aging (Albany NY) 2020, 12, 6511-6517. [CrossRef] [PubMed]

135. Chen, N.; Zhou, M.; Dong, X.; Qu, J.; Gong, F.; Han, Y.; Qiu, Y.; Wang, J.; Liu, Y.; Wei, Y.; et al. Epidemiological and clinical characteristics of 99 cases of 2019 novel coronavirus pneumonia in Wuhan, China: A descriptive study. Lancet 2020, 395, 507-513. [CrossRef]

136. Chan, V.W.; Chiu, P.K.; Yee, C.H.; Yuan, Y.; Ng, C.F.; Teoh, J.Y. A systematic review on COVID-19: Urological manifestations, viral RNA detection and special considerations in urological conditions. World J. Urol. 2020, 12. [CrossRef]

137. Mumm, J.N.; Osterman, A.; Ruzicka, M.; Stihl, C.; Vilsmaier, T.; Munker, D.; Khatamzas, E.; Giessen-Jung, C.; Stief, C.; Staehler, M.; et al. Urinary Frequency as a Possibly Overlooked Symptom in COVID-19 Patients: Does SARS-CoV-2 Cause Viral Cystitis? Eur. Urol. 2020, 78, 624-628. [CrossRef]

138. Varga, Z.; Flammer, A.J.; Steiger, P.; Haberecker, M.; Andermatt, R.; Zinkernagel, A.S.; Mehra, M.R.; Schuepbach, R.A.; Ruschitzka, F.; Moch, H. Endothelial cell infection and endotheliitis in COVID-19. Lancet 2020, 395, 1417-1418. [CrossRef]

139. Zhao, D.; Yao, F.; Wang, L.; Zheng, L.; Gao, Y.; Ye, J.; Guo, F.; Zhao, H.; Gao, R. A Comparative Study on the Clinical Features of Coronavirus 2019 (COVID-19) Pneumonia with Other Pneumonias. Clin. Infect. Dis. 2020, 71, 756-761. [CrossRef]

140. Zhang, H.; Kang, Z.; Gong, H.; Xu, D.; Wang, J.; Li, Z.; Li, Z.; Cui, X.; Xiao, J.; Zhan, J.; et al. Digestive system is a potential route of COVID-19: An analysis of single-cell coexpression pattern of key proteins in viral entry process. Gut 2020, 69, 1010-1018. [CrossRef]

141. Muus, C.; Luecken, M.D.; Eraslan, G.; Waghray, A.; Heimberg, G.; Sikkema, L.; Kobayashi, Y.; Vaishnav, E.D.; Subramanian, A.; Smilie, C.; et al. Integrated analyses of single-cell atlases reveal age, gender, and smoking status associations with cell type-specific expression of mediators of SARS-CoV-2 viral entry and highlights inflammatory programs in putative target cells. bioRxiv 2020. [CrossRef]

142. Holshue, M.L.; de Bolt, C.; Lindquist, S.; Lofy, K.H.; Wiesman, J.; Bruce, H.; Spitters, C.; Ericson, K.; Wilkerson, S.; Tural, A.; et al. First Case of 2019 Novel Coronavirus in the United States. N. Engl. J. Med. 2020, 382, 929-936. [CrossRef]

143. Lu, X.; Zhang, L.; Du, H.; Zhang, J.; Li, Y.Y.; Qu, J.; Zhang, W.; Wang, Y.; Bao, S.; Li, Y.; et al. SARS-CoV-2 Infection in Children. N. Engl. J. Med. 2020, 382, 1663-1665. [CrossRef] [PubMed]

144. Guan, W.J.; Ni, Z.Y.; Hu, Y.; Liang, W.H.; Ou, C.Q.; He, J.X.; Liu, L.; Shan, H.; Lei, C.L.; Hui, D.S.C.; et al. Clinical Characteristics of Coronavirus Disease 2019 in China. N. Engl. J. Med. 2020, 382, 1708-1720. [CrossRef] [PubMed]

145. Han, C.; Duan, C.; Zhang, S.; Spiegel, B.; Shi, H.; Wang, W.; Zhang, L.; Lin, R.; Liu, J.; Ding, Z.; et al. Digestive Symptoms in COVID-19 Patients with Mild Disease Severity: Clinical Presentation, Stool Viral RNA Testing, and Outcomes. Am. J. Gastroenterol. 2020, 115, 916-923. [CrossRef] [PubMed]

146. Carvalho, A.; Alqusairi, R.; Adams, A.; Paul, M.; Kothari, N.; Peters, S.; de Benedet, A.T. SARS-CoV-2 Gastrointestinal Infection Causing Hemorrhagic Colitis: Implications for Detection and Transmission of COVID-19 Disease. Am. J. Gastroenterol. 2020, 115, 942-946. [CrossRef]

147. Ferrey, A.J.; Choi, G.; Hanna, R.M.; Chang, Y.; Tantisattamo, E.; Ivaturi, K.; Park, E.; Nguyen, L.; Wang, B.; Tonthat, S.; et al. A Case of Novel Coronavirus Disease 19 in a Chronic Hemodialysis Patient Presenting with Gastroenteritis and Developing Severe Pulmonary Disease. Am. J. Nephrol. 2020, 51, 337-342. [CrossRef] 
148. Yang, L.; Han, Y.; Nilsson-Payant, B.E.; Gupta, V.; Wang, P.; Duan, X.; Tang, X.; Zhu, J.; Zhao, Z.; Jaffre, F.; et al. A Human Pluripotent Stem Cell-based Platform to Study SARS-CoV-2 Tropism and Model Virus Infection in Human Cells and Organoids. Cell Stem Cell 2020, 27, 125-136. [CrossRef]

149. Dirweesh, A.; Li, Y.; Trikudanathan, G.; Mallery, J.S.; Freeman, M.L.; Amateau, S.K. Clinical Outcomes of Acute Pancreatitis in Patients with Coronavirus Disease 2019. Gastroenterology 2020, 159, 1972-1974. [CrossRef]

150. Balaphas, A.; Gkoufa, K.; Meyer, J.; Peloso, A.; Bornand, A.; McKee, T.A.; Toso, C.; Popeskou, S.G. COVID-19 can mimic acute cholecystitis and is associated with the presence of viral RNA in the gallbladder wall. J. Hepatol. 2020, 73, 1566-1568. [CrossRef]

151. Hunt, R.H.; East, J.E.; Lanas, A.; Malfertheiner, P.; Satsangi, J.; Scarpignato, C.; Webb, G.J. COVID-19 and Gastrointestinal Disease. Implications for the Gastroenterologist. Dig. Dis. 2020, 39, 119-139. [CrossRef]

152. Yang, X.; Yu, Y.; Xu, J.; Shu, H.; Xia, J.; Liu, H.; Wu, Y.; Zhang, L.; Yu, Z.; Fang, M.; et al. Clinical course and outcomes of critically ill patients with SARS-CoV-2 pneumonia in Wuhan, China: A single-centered, retrospective, observational study. Lancet Respir. Med. 2020, 8, 475-481. [CrossRef]

153. Lanas, A.; Dumonceau, J.M.; Hunt, R.H.; Fujishiro, M.; Scheiman, J.M.; Gralnek, I.M.; Campbell, H.E.; Rostom, A.; Villanueva, C.; Sung, J.J.Y. Non-variceal upper gastrointestinal bleeding. Nat. Rev. Dis. Primers 2018, 4, 18020. [CrossRef]

154. Massironi, S.; Vigano, C.; Dioscoridi, L.; Filippi, E.; Pagliarulo, M.; Manfredi, G.; Conti, C.B.; Signorelli, C.; Redaelli, A.E.; Bonato, G.; et al. Endoscopic Findings in Patients Infected with 2019 Novel Coronavirus in Lombardy, Italy. Clin. Gastroenterol. Hepatol. 2020, 18, 2375-2377. [CrossRef]

155. Farina, D.; Rondi, P.; Botturi, E.; Renzulli, M.; Borghesi, A.; Guelfi, D.; Ravanelli, M. Gastrointestinal: Bowel ischemia in a suspected coronavirus disease (COVID-19) patient. J. Gastroenterol. Hepatol. 2021, 36, 41. [CrossRef]

156. Connors, J.M.; Levy, J.H. COVID-19 and its implications for thrombosis and anticoagulation. Blood 2020, 135, $2033-2040$. [CrossRef]

157. Artifoni, M.; Danic, G.; Gautier, G.; Gicquel, P.; Boutoille, D.; Raffi, F.; Neel, A.; Lecomte, R. Systematic assessment of venous thromboembolism in COVID-19 patients receiving thromboprophylaxis: Incidence and role of D-dimer as predictive factors. $J$. Thromb Thrombolysis 2020, 50, 211-216. [CrossRef]

158. Xu, L.; Liu, J.; Lu, M.; Yang, D.; Zheng, X. Liver injury during highly pathogenic human coronavirus infections. Liver Int. 2020, 40, 998-1004. [CrossRef]

159. Li, Y.C.; Bai, W.Z.; Hashikawa, T. The neuroinvasive potential of SARS-CoV2 may play a role in the respiratory failure of COVID-19 patients. J. Med. Virol. 2020, 92, 552-555. [CrossRef]

160. Uhlen, M.; Fagerberg, L.; Hallstrom, B.M.; Lindskog, C.; Oksvold, P.; Mardinoglu, A.; Sivertsson, A.; Kampf, C.; Sjostedt, E.; Asplund, A.; et al. Proteomics. Tissue-based map of the human proteome. Science 2015, 347, 1260419. [CrossRef]

161. Dube, M.; le Coupanec, A.; Wong, A.H.M.; Rini, J.M.; Desforges, M.; Talbot, P.J. Axonal Transport Enables Neuron-to-Neuron Propagation of Human Coronavirus OC43. J. Virol. 2018, 92. [CrossRef]

162. Desforges, M.; le Coupanec, A.; Brison, E.; Meessen-Pinard, M.; Talbot, P.J. Neuroinvasive and neurotropic human respiratory coronaviruses: Potential neurovirulent agents in humans. Adv. Exp. Med. Biol. 2014, 807, 75-96. [CrossRef]

163. Keyhanian, K.; Umeton, R.P.; Mohit, B.; Davoudi, V.; Hajighasemi, F.; Ghasemi, M. SARS-CoV-2 and nervous system: From pathogenesis to clinical manifestation. J. Neuroimmunol. 2020, 350, 577436. [CrossRef]

164. Prabakaran, P.; Xiao, X.; Dimitrov, D.S. A model of the ACE2 structure and function as a SARS-CoV receptor. Biochem. Biophys. Res. Commun. 2004, 314, 235-241. [CrossRef]

165. Abboud, H.; Abboud, F.Z.; Kharbouch, H.; Arkha, Y.; el Abbadi, N.; el Ouahabi, A. COVID-19 and SARS-Cov-2 Infection: Pathophysiology and Clinical Effects on the Nervous System. World Neurosurg. 2020, 140, 49-53. [CrossRef]

166. Xia, H.; Lazartigues, E. Angiotensin-converting enzyme 2: Central regulator for cardiovascular function. Curr. Hypertens. Rep. 2010, 12, 170-175. [CrossRef]

167. Siso, S.; Jeffrey, M.; Gonzalez, L. Sensory circumventricular organs in health and disease. Acta Neuropathol. 2010, 120, 689-705. [CrossRef]

168. Bohmwald, K.; Galvez, N.M.S.; Rios, M.; Kalergis, A.M. Neurologic Alterations Due to Respiratory Virus Infections. Front. Cell Neurosci. 2018, 12, 386. [CrossRef]

169. De Wit, E.; van Doremalen, N.; Falzarano, D.; Munster, V.J. SARS and MERS: Recent insights into emerging coronaviruses. Nat. Rev. Microbiol. 2016, 14, 523-534. [CrossRef]

170. Wu, Y.; Xu, X.; Chen, Z.; Duan, J.; Hashimoto, K.; Yang, L.; Liu, C.; Yang, C. Nervous system involvement after infection with COVID-19 and other coronaviruses. Brain Behav. Immun. 2020, 87, 18-22. [CrossRef]

171. Poyiadji, N.; Shahin, G.; Noujaim, D.; Stone, M.; Patel, S.; Griffith, B. COVID-19-associated Acute Hemorrhagic Necrotizing Encephalopathy: Imaging Features. Radiology 2020, 296, E119-E120. [CrossRef] [PubMed]

172. Filatov, A.; Sharma, P.; Hindi, F.; Espinosa, P.S. Neurological Complications of Coronavirus Disease (COVID-19): Encephalopathy. Cureus 2020, 12, e7352. [CrossRef] [PubMed]

173. Driessen, A.K.; Farrell, M.J.; Mazzone, S.B.; McGovern, A.E. Multiple neural circuits mediating airway sensations: Recent advances in the neurobiology of the urge-to-cough. Respir. Physiol. Neurobiol. 2016, 226, 115-120. [CrossRef] [PubMed]

174. Lochhead, J.J.; Thorne, R.G. Intranasal delivery of biologics to the central nervous system. Adv. Drug Deliv. Rev. 2012, 64, 614-628. [CrossRef] 
175. Audrit, K.J.; Delventhal, L.; Aydin, O.; Nassenstein, C. The nervous system of airways and its remodeling in inflammatory lung diseases. Cell Tissue Res. 2017, 367, 571-590. [CrossRef]

176. Mao, L.; Jin, H.; Wang, M.; Hu, Y.; Chen, S.; He, Q.; Chang, J.; Hong, C.; Zhou, Y.; Wang, D.; et al. Neurologic Manifestations of Hospitalized Patients with Coronavirus Disease 2019 in Wuhan, China. JAMA Neurol. 2020, 77, 683-690. [CrossRef]

177. Sasannejad, C.; Ely, E.W.; Lahiri, S. Long-term cognitive impairment after acute respiratory distress syndrome: A review of clinical impact and pathophysiological mechanisms. Crit. Care 2019, 23, 352. [CrossRef]

178. Xu, J.; Zhong, S.; Liu, J.; Li, L.; Li, Y.; Wu, X.; Li, Z.; Deng, P.; Zhang, J.; Zhong, N.; et al. Detection of severe acute respiratory syndrome coronavirus in the brain: Potential role of the chemokine mig in pathogenesis. Clin. Infect. Dis. 2005, 41, 1089-1096. [CrossRef]

179. Mehta, P.; McAuley, D.F.; Brown, M.; Sanchez, E.; Tattersall, R.S.; Manson, J.J.; Hlh Across Speciality Collaboration, UK. COVID-19: Consider cytokine storm syndromes and immunosuppression. Lancet 2020, 395, 1033-1034. [CrossRef]

180. Menghini, R.; Campia, U.; Tesauro, M.; Marino, A.; Rovella, V.; Rodia, G.; Schinzari, F.; Tolusso, B.; di Daniele, N.; Federici, M.; et al. Toll-like receptor 4 mediates endothelial cell activation through NF-kappaB but is not associated with endothelial dysfunction in patients with rheumatoid arthritis. PLoS ONE 2014, 9, e99053. [CrossRef]

181. Rothan, H.A.; Byrareddy, S.N. The epidemiology and pathogenesis of coronavirus disease (COVID-19) outbreak. J. Autoimmun. 2020, 109, 102433. [CrossRef]

182. Steardo, L., Jr.; Bronzuoli, M.R.; Iacomino, A.; Esposito, G.; Steardo, L.; Scuderi, C. Does neuroinflammation turn on the flame in Alzheimer's disease? Focus on astrocytes. Front. Neurosci. 2015, 9, 259. [CrossRef]

183. Verkhratsky, A.; Rodriguez, J.J.; Steardo, L. Astrogliopathology: A central element of neuropsychiatric diseases? Neuroscientist 2014, 20, 576-588. [CrossRef]

184. Peters, R. Ageing and the brain. Postgrad. Med. J. 2006, 82, 84-88. [CrossRef]

185. Jiang, F.; Deng, L.; Zhang, L.; Cai, Y.; Cheung, C.W.; Xia, Z. Review of the Clinical Characteristics of Coronavirus Disease 2019 (COVID-19). J. Gen. Intern. Med. 2020, 35, 1545-1549. [CrossRef]

186. Taylor, C.T.; Doherty, G.; Fallon, P.G.; Cummins, E.P. Hypoxia-dependent regulation of inflammatory pathways in immune cells. J. Clin. Investig. 2016, 126, 3716-3724. [CrossRef]

187. Calcia, M.A.; Bonsall, D.R.; Bloomfield, P.S.; Selvaraj, S.; Barichello, T.; Howes, O.D. Stress and neuroinflammation: A systematic review of the effects of stress on microglia and the implications for mental illness. Psychopharmacology (Berl.) 2016, 233, 1637-1650. [CrossRef]

188. Klein, R.S.; Garber, C.; Funk, K.E.; Salimi, H.; Soung, A.; Kanmogne, M.; Manivasagam, S.; Agner, S.; Cain, M. Neuroinflammation During RNA Viral Infections. Annu. Rev. Immunol. 2019, 37, 73-95. [CrossRef]

189. Tang, N.; Bai, H.; Chen, X.; Gong, J.; Li, D.; Sun, Z. Anticoagulant treatment is associated with decreased mortality in severe coronavirus disease 2019 patients with coagulopathy. J. Thromb Haemost. 2020, 18, 1094-1099. [CrossRef] [PubMed]

190. Bobker, S.M.; Robbins, M.S. COVID-19 and Headache: A Primer for Trainees. Headache 2020, 60, 1806-1811. [CrossRef] [PubMed]

191. Ponti, G.; Maccaferri, M.; Ruini, C.; Tomasi, A.; Ozben, T. Biomarkers associated with COVID-19 disease progression. Crit. Rev. Clin. Lab. Sci. 2020, 57, 389-399. [CrossRef] [PubMed]

192. Kermali, M.; Khalsa, R.K.; Pillai, K.; Ismail, Z.; Harky, A. The role of biomarkers in diagnosis of COVID-19—A systematic review. Life Sci. 2020, 254, 117788. [CrossRef]

193. Tietjen, G.E.; Khubchandani, J.; Herial, N.; Palm-Meinders, I.H.; Koppen, H.; Terwindt, G.M.; van Buchem, M.A.; Launer, L.J.; Ferrari, M.D.; Kruit, M.C. Migraine and vascular disease biomarkers: A population-based case-control study. Cephalalgia 2018, 38, 511-518. [CrossRef]

194. Fong, T.G.; Tulebaev, S.R.; Inouye, S.K. Delirium in elderly adults: Diagnosis, prevention and treatment. Nat. Rev. Neurol. 2009, 5, 210-220. [CrossRef]

195. FSD Pharma. Ultramicronized Palmitoylethanolamide (PEA) Treatment in Hospitalized Participants with COVID-19; NCT04619706; FSD Pharma: Cobourg, Canada, 2020. 